\title{
LAW AND THE LEGISLATIVE PROCESS IN OCCUPIED GERMANY: 1*
}

\author{
KARL LOEWENSTEIN $\dagger$
}

\section{INTRODUCTION}

THE interest of the American legal profession in the occupation of Germany is primarily focused-beyond the major political implications for a lasting peace - on two interrelated aspects: reconstruction of the system of administering law to conform with democratic standards, and the nature of the law itself. The first of these has been discussed by this writer elsewhere. ${ }^{1}$ The present study proposes to describe and critically review the efforts of the occupation authorities-in particular, American Military Government-to provide the German people with a body of democratic law.

This task implies the discussion of what has been done negatively, to eradicate Nazi legislation and, positively, to replace it. Equally relevant is treatment of the methods employed by the occupying authorities to accomplish the objective.

This article will, then, begin with a presentation of the political background against which the work of legislative reform may be viewed.

After an examination of the various alternatives for the execution of legislative reform, a structural analysis will be presented of the actual law-making process of the different levels of Military Governmentquadripartite and zonal-and of the varied German legislative agencies. In this context, the actual work of legislative reform will be set out and discussed.

* This is the first of two parts. Part II will appear in the next issue of the JourNal.

$\dagger$ Professor of Political Science and Jurisprudence, Amherst College; Member of the Massachusetts Bar; Special Assistant to the Attorney General, 1942-1944. The author was privileged to serve, from July, 1945 to September, 1946, as Legal Advisor in the Office of Military Government for Germany (United States), attached as Consultant to the Administration of Justice Branch of the Legal Division in Berlin.

- 1. Loewenstein, Reconstruction of the Administration of Justice in American-Occupied Germany, 61 HARv. L. REv. 419 (1948).

The material covered by this article extends roughly to January, 1948.

The following abbreviations are used in the footnotes: MG for Military Government; AMG for American Military Government; CC for Control Council (Allied Control Authority); SHAEF for Supreme Headquarters Allied Expeditionary Forces (denoting the period of combat and the time immediately following surrender, prior to the partition of Germany into four zones of occupation); USFET for United States Forces European Theater; OMGUS for Office of Military Government for Germany (United States); MGR for Military Government Regulations (issued by Hq. USFET, OMGUS); OG for Official Gazette (of both the Control Council and Military Government in the United States Zone); RGB1. for Reichsgesetzblatt (the official publication of statutes of the German Reich); GVBI. for Gesetz-sme Verordnungsblatt (the official publication of statutes of the Länder of Bavaria and Greater Hesse); RegBl. for Regicrungsblatt (the official publication of statutes of Land Württemberg-Bade); SJZ for Silddeutschc Juristenzeitung (to date the only law journal in the United States Zone). 


\section{Political Background}

Upon the entry of the Allied forces into western Germany, supreme legislative, executive and judicial authority in the occupied area was vested in General Eisenhower as the Allied Supreme Commander. Military Government was established to exercise these powers under his direction. ${ }^{2}$ By the Four Power Statement of June 5, 1915, the InterAllied Control Authority, or Control Council, was established in Berlin as the supreme authority for occupied Germany in lieu of the non-existing central German government. ${ }^{3}$ The basic charter for the quadripartite government of occupied Germany is the "Report on the Tripartite Conference of Berlin," published on August 2, $1945^{4}$ and known as the Potsdam Declaration. By Proclamation No. 1 of the Control Council of August $30,1945^{5}$ the German people were notified that supreme authority "in matters affecting Germany as a whole" was conferred upon the Council. ${ }^{6}$

The Zone assigned to the United States embraces in southern Germany the Länder ' (states) of Bavaria, Württemberg-Bade (consisting of the northern halves only of these previously separate states), and Greater Hesse (since 1947 officially called Hesse), a new political entity carved out of the former Land Hesse and two adjacent former Prussian provinces. Land Bremen, in northwestern Germany, also belongs to the United States Zone. ${ }^{8}$

2. Proclamation No. 1, Art. II, OG/MIG, Issue A, at 1 (June 1, 1946) and $\mathbf{M G R}$, 23.200; of the latter, primarily Title 5 (Legal and Penal Administration) and Title 23 (Military Government Legislation) are relevant for this discussion. Two editions of Title 5 are used side by side, the first issued in the early stages of the occupation and applicable to the United States Zone through 1946; the second (officially styled Change 1 and superseding the preceding one), issued March 27, 1947. In Title 23 the first edition (Change 1) is dated April 12, 1946, the second (Change 18) January 22, 1947. If not otherwise indicated the texts referred to are identical in either edition.

3. OG/CC, Supp. No. 1 at 10 (April 30, 1946). This publication [see CC Directive No. 11 of Sept. 22, 1945, OG/CC, No. 3 at 39 (Jan. 31, 1946)] is issued at irregular intervals in the three official languages, English, French and Russian, together with an (unofficial) German translation; on the translation and publication problems, see p. 743 infro.

4. OG/CC, Supp. No. 1 at 13 (April 30, 1946).

5. OG/CC, No. 1 at 4 (Oct. 29, 1945).

6. On the CC see Special Report of the Military Governor, United States Zone, March 15, 1947, on "Governmental Organization in the Occupied Zones of Germany," p. 3; Loewenstein, Political Reconstrution in Germany, Zonal and Intcronal in Crasice and Crisis in European Governarent 30 (Pollock, ed. 1947); Whyte, Quadrigartite Rule in Berlin, International Afrairs, Jan. 1947, p. 20.

7. The states of the American Zone, now officially termed Länder (singular: Lord), were established by Proclamation No. 2 (USFET), Sept. 19, 1945, OG/AIG, Issue A at 2.

8. Constituted by Proclamation No. 3, Jan. 21, 1947, OG/AIG, Issue C at 1 (April 1, 1947). The Bremen Enclave, embracing the Free City of Bremen, and the adjacent counties including Wesermünde (with Bremerhaven), at first was under American jurisdiction, serving as a port of supply for the United States forces. The confusion arising from its location in the British Zone resulted in the transfer of the territory, with the 
The formation of indigenous German governments in the Länder was beset with difficulties, largely due to the unfamiliarity of the Land Military Commanders with political conditions. In the fall of 1945, however, German governments began to function in an experimental fashion. In October, 1945 the Länderrat (Regional Council) ${ }^{9}$ was constituted in Stuttgart. It consists of the Minister Presidents of the Länder (for technical reasons the chief executive [Oberburgermeister] of Bremen was not a member until January, 1947), meeting at least once a month for action on problems whose common resolution is believed to be in the interest of all of the Länder. They are assisted by a German staff of functional experts and a permanent secretariat acting as a steering committee. In cooperation with officials of the Regional Coordinating Office of American Military Government in Stuttgart who guided and supervised its work without, however, directing it, the Länderrat in due course became in a skeletal form a zonal legislative authority for the Länder in the United States Zone. ${ }^{10}$ Although the decisions of the Minister Presidents, not formally binding on the individual Länder, must be promulgated separately by each Minister President for his Land, adoption of a measure by the Länderrat in practice amounts to uniform legislation throughout the United States Zone.

To the governments of the Länder were assigned, subject to authority of American Military Government, ${ }^{11}$ full legislative, executive and

exception of the city of Bremen itself and the Stadtkreis (city district) of Wescrminde, to the British on December 10,1945. By agreement of January 21, 1947, however, the city and the county of Bremen and the Stadtkreis of Wesermünde, renamed Bremerhaven, returned to American jurisdiction as a full-fledged state in the United States Zone, on a par with the three southern Länder; see Proclamation No. 3, Jan. 21, 1947, OG/MG, Issue $C$ at 1 (April 1,1947). In view of the fact that the German administrative boundaries do not coincide with AMG jurisdiction the situation is still unsatisfactory. On the general situation in Bremen see Special Report of the Military Governor, United States Zone, op. cit. supra note 6, at 25 et seq. This article does not discuss Land Bremen for reasons of space and lack of adequate information.

9. For the statute of the Länderrat and other relevant documentary material see Poliock and Meisel, Germany Under Occupation, Illustrative Materinls and Documenrs 126 et seq. (1947). See also articles by Loewenstein and Pollock in Crinnge and Crisis in European Government, 29, 36 and 45, 50 (Pollock ed. 1947). On the Länderrat, see Special Report of the Military Governor, United States Zone, op. cit. supra note 6 , at 4-5.

10. At the same time the Länderrat was constituted, a committee of the Ministers of Justice of the Länder was created to deal with legal matters affecting all of them. Subsequently it was incorporated into the Länderrat as one of its many technical committces. See Administration of Justice (USFET Hq. Directive, Oct. 4, 1945), 14 GEC-AGO.

11. On the development of American Military Government in general see HoldorN, AMrerican MUITARy Government (1947); for a more critical discussion of its operations see Zink, American Miritary Government in Germany (1947); sec also Loewenstein, op. cit. supra note 9, at 29 et seq., and Pollock op. cit. supra note 9, at 45 et seq. Information on the legal work of AMG may be found in Fahy, The Laweyer in Military 
judicial powers except as their exercise would conflict with action taken by the Control Council or by any central German authority established by it. For an interim period, until the establishment of functioning democratic institutions, the validity of such state legislation was made dependent on approval and promulgation by the Minister President of each Land. ${ }^{12}$ German law was to remain in force until repealed or suspended by a new law enacted either by the Control Council for Germany as a whole, or by American Military Government for the Zone, or by its government for the Land. ${ }^{13}$

In line with the basic policies of the Potsdam Declaration, ${ }^{14}$ democratic self-government in the United States Zone was built up systematically and swiftly during 1946. Following the elections of administrative bodies for the rural communities (Landgemeinden) (January 30), of county councils (Landkreise) (April 2S), and city councils of the larger towns (Stadtkreise) (May 28), constitutional conventions were elected on June 30 . The constitutions drafted by the latter, upon approval by American Military Government were accepted by referenda of the German people in each state on November 24 and December 1. By January, 1947 the Länder in the United States Zone had reached the stage of popularly elected parliaments (Landtage) with governments responsible to them under constitutions.

The termination of the period of "indirect" government by American Military Government is clearly reflected by Proclamation No. 4 of March 1, 1947, ${ }^{15}$ stating that full legislative, executive and judicial power exists in the three south German states according to their constitutions - effective also in Land Bremen upon adoption of a constitution $\rightarrow$ subject only to international agreements to which the United States is a party; to quadripartite legislation; and to the powers reserved to American Military Government in order to effectuate basic policies of the occupation. ${ }^{16}$ Whether these limitations embrace bizonal agree-

Government in Gernany, 15 DeP'T STATE BuLL. 852 (1946); Nobleman, The Administration of Justice in the United States Zone of Germany, 8 FED. BAB J. 70 (1946); Deutsch, Military Government Administration of Occupied Territory, 33 A. B. A. J. 133 (1947). For an excellent monograph on education and religious activities see Krispza:, And CaLI IT PEACE (1947).

12. Proclamation No. 2, Art. III, OG/MIG, Issue A at 2 (June 1, 1946).

13. Id., Art. II.

14. OG/CC, Supp. No. 1 at 13 et seq. (April 30, 1946). See id., A(3): "The purposes of the occupation of Germany .... are ... (IV) To prepare for the eventual reconstruction of German political life on a democratic basis. . .."; and id., A(9): "The administration of ... Germany should be directed towards the decentralization of the political structure and the development of local responsibility. To this end, ... (III) representative and elective principles shall be introduced into regional, provincial and state (Land) administration as rapidly as may be justified by the successful applieation of these principles in local self-government."

15. OG/MG, Issue $C$ at 1 (April 1, 1947).

16. Only in the fields so reserved does MIG Proclamation No. 2 remain in applieation; 
ments is not explicitly mentioned. To all intents and purposes, the four Län'der in the United States Zone have thus regained full self-government if not sovereignty within the limits of American Military Government occupation. In consequence, the functions of American Military Government are today limited largely to "observation, inspection, reporting and advising." 17

When French and Soviet opposition to the establishment of the central agencies provided for in the Potsdam Declaration ${ }^{18}$ made it evident that Germany could not be treated, for the time being, as an economic whole, economic fusion of the United States and the British Zones was agreed upon by Secretary of State Byrnes and Foreign Secretary Bevin. ${ }^{19}$ The bizonal merger entered into effect on January 1, 1947.

At first, five separate executive committees for economics, transport, communication, food and agriculture, finance and civil service, composed of German experts from both zones and supervised by combined American-British Military Government boards, were set up. This first attempt at overcoming the zonal partition of Germany proved wholly unsatisfactory. The committees were so widely dispersed over the zones ${ }^{20}$ that they lacked proper integration and centralized coordination. And, although their members, appointed by joint Military Government action, had no democratic mandate, the committees from the start were exposed to party politics. Moreover, for the execution of their decisions they were dependent on the good will of the Länder since they did not possess enforcement powers. In order to prevent impending breakdown and "for the purpose only of a more complete economic integration" a bizonal reorganization was agreed upon by the United States and British Military Governments on May 29, 1947.21

Under the new plan a German Economic Council (Wirtschaftsrat)

legislation in reserved fields is approved and promulgated by the Minister Presidents with advance approval of AMG in line with Article III of Proclamation No. 2, OG/MG, Issue A at 2 (June 1, 1946).

17. United States MG Directive (Sept. 30, 1946), AGO 010.1. For text sce Pollock AND MEISEL, op. cit. supra note 9, at 174.

18. These were envisaged in the fields of finance, transport, communications, forcign trade, and industry; see Report on the Tripartite Conference of Berlin, A(9) (IV), OG/CC, Supp. No. 1 at 15 (April 30, 1946).

19. December 2, 1946. For text see Pollock and Mersel, op. cit. supra note 9, at 240 et seq.; on the Anglo-American merger in general see Pollock, American Policy touturds Germany, 23 Foreign Policy Reports 198, 203 (1947). For a fuller and authoritative description of the bizonal structure in all stages see Civir Adununistration Division (OMGUS), The Evolution of Bizonal Organization (1948).

20. Economics and transport were located in the British Zone in Minden and Bielefeld respectively, food in Stuttgart, the others in Frankfurt.

21. For text see $O G / M G$, Issue $E$ at 2 (Aug. 1, 1947). The agreement was made effective in the United States Zone by Proclamation No. 5, June 2, 1947, OG/MG, Issue E at 1 (Aug. 1, 1947). The Council first convened at Frankfurt, June 25, 1947. 
and a German Executive Committee (Exekutizausschuss) were established, both operating under joint British and American supervision exercised through a combined Bipartite Board, a Bipartite Control Office and Bipartite Panels. The Economic Council consisted of 54 representatives chosen by the parliaments of the states in both zones, 22 a Land being entitled to one seat for each population unit of 750,000 with seats allocated by each Land in proportion to the division of political opinion shown by popular vote in the most recent Land-wide election. The Council was equipped with wide legislative powers in the economic field. ${ }^{23}$ The Executive Committee, consisting of eight representatives (one from each Land appointed by the Land governments) was charged with coordination, supervision and implementation of the ordinances issued by the Council. Under the Committee were five executive directors as heads of the bizonal departments, selected from nominations of the Committee and appointed and removed by the Council; these men were the operating head officials of the economically merged zones, approximating the functions of ministers or department chiefs. ${ }^{24}$

Ordinances and implementing regulations of the Economic Council were binding on the Länder and had to be promptly executed by them. But while these indigenous German bodies were given paramount legislative powers over the economic life of the merged zones, subject only to the veto of the combined Military Governments, they were not fully democratically constituted and their relationship to the governments and parliaments of the Länder remained oblique. Though possessing a genuine law-making function in the assigned economic fields they lacked the corresponding enforcement powers which to a large extent continued to be vested in the Land governments.

After the breakdown of the London Conference of Foreign Ministers in December, 1947, American and British Military Governments decided to convert the hybrid system of intermediary economic agencies into a genuinely unified economic.administration of the two zones. On January 7,1948 the new plan was proposed, ${ }^{25}$ becoming effective on February 9. The size of the Economic Council was doubled, its 104

22. II (a) of sub-heading "Organization \& Functions" of "Agrcement for the Reorganization of Bizonal Economic Agencies," published as Appendis: A to Proclamation No. 5 OG/AFG, Issue $\mathrm{E}$ at 2 (Aug. 1, 1947). The amendment in Prodamation No. 6, $O G / M G$, Issue $F$ at 1 (Oct. 31, 1947), ordered that members of Landloge and Land cabinets resign their seats when accepting election to the Economic Council.

23. See id., II 1 (b).

24. The offices of the five directorships were all occupied by members or partisans of the conservative Christian Democratic Union. When the other leading party; the Social Democrats, failed to obtain the Economic Directorship in August, 1947, they refused to accept any responsibility for the work of the Economic Council and considered themselves an opposition party.

25. See N.Y. Times, Jan. 8, 1948, p. 1, col. 1, and see Polroek axd Mrerser, op. cit. supra note 9 , at 240 et seq. 
members being elected by the Landtage by proportional representation. In all economic matters the bizonal parliament has full legislative authority and its enforcement powers override those of the Länder.

It elects a chief executive who in turn, with the approval of the Council, appoints a five-member cabinet in charge of the departments of economics, finance, food and agriculture, communications and transportation (to which labor and public welfare may be added). An upper house, composed of two members from each Land, possesses a qualified veto. Economic unification is implemented by a bizonal central bank and a nine-man supreme court for economic disputes, the latter urgently required because the diversification of adjudication patterns seriously threatens legal unity.

Simultaneously it was announced that American and British Military Governments would completely merge their operational offices in economic matters, on the pattern of the Anglo-American staff integration of SHAEF.

The reform constitutes a further reversal, dictated by realities, of the original rigid doctrine of economic and political decentralization. Admittedly it is still of an emergency nature and lacks the democratic legitimation which only an elected national assembly of the two zones can confer. But a working frame is presented which, at the proper time, by the addition of the political departments, in particular foreign affairs, interior and justice, can develop into a full-fledged political state encompassing the two zones. Thus, the new system may serve as the organizational nucleus for a unified all-German state if and when the other powers and their subordinated zones choose to accede.

\section{Theory and Practice of Legislative Reform}

\section{(I) Denazification of Law as an Occupation Objective}

The term "denazification" commonly refers to the human element, that is to the removal of Nazi-tainted personnel from public, social, and economic life in Germany. ${ }^{26}$ Less familiarly, it denotes the elimination of Nazi institutions, concepts and techniques from German law and legislation, and, where required, their replacement by democratic measures and standards. It is this second aspect with which this discussion will deal. Confining itself, however, to the principles and methods applied in legislative reform, it will advert to the substance only insofar as analysis of the legislative process may require.

26. This objective of the occupation, more controversial than any other, has not yet found an adequate over-all discussion. For preliminary observations see $Z_{\text {IN }}$, op. cit. supra note 11, at 130 et seq.; Plischke, Denazification Law and Procedture, 41 Ar. J. INT'L L. 807 (1947) ; Plischke, Denazifying the Reich, 9 The Review of Poutrics 153 et seq. (1947); Loewenstein, op. cit. supra note 6 , at 33 . On the denazification of legal personnel see Loewenstein, op. cit. supra note 1, at 442 et seq. 
Legislative reform with its focus on denazification constituted an official occupation objective. Joint Chiefs of Staff Directive 1067, 27 the initial authority, instructed General Eisenhower that "the laws purporting to establish the political structure of National Socialism and the basis of the Hitler regime, and all laws, decrees and regulations which establish discriminations on grounds of race, nationality, creed, or political opinion, should be abrogated by the Control Council. You will abrogate them in your zone." 23

The Potsdam Declaration, not much more specific on legal matters, repeated this injunction, ${ }^{29}$ adding that "No such discriminations, whether legal, administrative or otherwise, shall be tolerated." For the United States Zone, Military Government Law No. 1 (SHAEF) ${ }^{39}$ stipulated: "No German law, however or whenever enacted or enunciated, shall be applied judicially or administratively within the occupied territory in any instance where such application would cause injustice or inequality, either (a) by favoring any person because of his connection with the National Socialist Party, its formations or affiliated or supervised organizations, or (b) by discriminating against any person by reason of his race, nationality, religious beliefs or opposition to the National Socialist Party or its doctrines," and implemented the prohibition by elaborate "general interpretation clauses" addressed specifically to German courts and agencies. ${ }^{31}$ Military Government Regulations restate the Potsdam provision verbatim, ${ }^{32}$ aiming in general at establishment by the German authorities of a system of administration of justice in the United States Zone "in accordance with the principles of democracy, of justice under law, and of equal rights for all persons without distinction of race, nationality, or religion," a formulation which implicitly may seem to require, beyond its concentration on procedural and administrative issues, reformation of the existing law in conformity with these ideals. ${ }^{33}$

27. 13 Dep't State Bull 596-607 (1945). This notorious document, said to have been inspired by the so-called Morgenthau plan, was sent by the Joint Chiefs of Staff to General Eisenhower on April 28, 1945.

28. Id., 6 (b) ; the instruction is repeated in relation to tasation matters (48 (b)).

29. III A (4), OG/CC Supp. No. 1 at 13 (April 30, 1946).

30. OG/MG, Issue A at 3, Art. II (June 1, 1946).

31. Id., Art. III (repeated also in Art. II of CC Law No. 1 OG/CC, No. 1 at 6, 7 (Oct. 29, 1945)). In particular are forbidden, in the interpretation and applieation of German law, references to legal authorities or decisions "expounding or applying Niational Socialist objectives or doctrines." German law enacted after January 30, 1933 and remaining in force is to be applied in accordance with "the plain meaning of the test and without regard to ... meanings ascribed in preambles and other pronouncements"; the latter injunction refers to the Nazi habit of raising the preamble of a statute, usually containing ideological directives, to the rank of a formal legal provision.

32. MIGR 5.100 (d).

33. A more direct reference to this task is contained in AIGR 5.105, maling legal officers responsible "for the study of German legislation with respect to the suspension or suppression of such parts thereof as may be required to carry out the policies laid down by the CC, or MIG." 
The new Directive of July 15, $1947^{34}$ is silent on this issue, either because the task is believed to be completed, or no longer important, or because legislative reform is now not felt to be a function of American Military Government.

\section{(2) Repeal of the Nazi "Political" Legislation}

The abrogation of the laws on which the political structure of the Nazi regime was based was a relatively simple task requiring little research; any elementary Nazi textbook on constitutional law and many foreign descriptions enumerated those statutes pertinent to the objective. In the American and British occupied territories the instruction was duly carried out by Military Government Law No. 1 (SHAEF) and its Regulation No. 1, the former repealing nine "basic" Nazi statutes," the latter nullifying certain enactments issued for their execution. ${ }^{35}$ Control Council Law No. 1, of September 20, 1945, followed suit, abrogating for Germany as a whole twenty-five named measures. ${ }^{30}$

Additional statutes, without question belonging to the "political structure of the regime," were abrogated by the Control Council subsequently though in many cases only after considerable disputes over

34. 15 Dep't State Bult. 186-202 (1947).

35. OG/MG, Issue $A$ at 3 and 5 (June 1, 1946). The Regulation enumerates thirtyfive executory ordinances, and, in Part II, abrogates, in addition, legislation most flagrantly discriminating against the Jews, based primarily on the so-called Nuremberg laws, namely the Lav "for the Protection of the German Blood and Honor" and the Reich Citizenship Law, both of September 15, 1935, [1935] RGB1. I, 1146-7. The list is declared not to be exhaustive.

36. OG/CC, No. 1 at 6 (Oct. 29, 1945); CC Law No. 1 and MG Law No. 1 of course cover substantially the same ground though the former is more exhaustive on the basic political enactments. Among the laws abolished are the Enabling Act of March 24, 1933, [1933] RGB1. I, 141; the Law of July 14, 1933 "Against the Creation of Political Parties," [1933] RGB1. I, 479; the Law of Dec. 1, 1933 "Securing the Unity of Party and State," [1933] RGB1. I, 1016; and the Prussian law of February 10, 1936 concerning the Gelieime Staatspolizei (Gestapo) (Gesetzssammlung, p. 21).

Statutes whose repeal by the occupation powers would have reflected an intention to restore the Weimar republic were not included. The Law on "Plebiscites" of July 14, 1933, [1933] RGB1. I, 479, was abrogated by CC Law No. 1 since here a basically democratic institution had been perverted for Nazi purposes. However, the wholesale repeal of all "supplementary and explanatory laws, ordinances and decrees," CC Law No. 1, Art. I (1), could not fail to lead to considerable difficulties. For example, the Eleventh Ordinance to the Reich Citizenship Law of November 25, 1941, [1941] RGB1. I, 722 deprived all emigrated Jews of their German nationality. Did the repeal of this ordinance automatically restore them to German nationality, obviously against their will? The doubt arose from Art. I (2), stating that "The abrogation of the above mentioned laws does not revive any law enacted subsequent to January 30,1933 , which was thereby repealed." In the United States Zone the issue subsequently was solved administratively by USFET Circular No. 181, treating as Germans all those who were formerly German nationals, except those who had lost German nationality under the Eleventh Ordinance of November 25, 1941. 
how the gap left by their elimination should, or could, be filled. Illustrations are the repeal of the Nazi "Labor Charter" si and of the entire legislative pattern governing hereditary farms and similar entailed property. ${ }^{3 s}$ From the historical viewpoint, perhaps the most momentous enactment in this class is the abolition of the State of Prussia; ${ }^{33}$ wiping Prussia off the map-at least by fiat of the conquerors-of course was not motivated by the Nazi character of Prussia, but, as stated in the preamble to the statute, was done because "The Prussian state which from early days has been a bearer of militarism and reaction in Germany has de facto ceased to exist."

\section{(3) The Nazi Legal Heritage}

The first part of the Potsdam injunction, referring to the abrogation of the "political" Nazi laws, thus was carried out satisfactorily. The second, however, dealing with the repeal of all regulations discriminatory on grounds of race, nationality, creed, or political opinion-not to mention provisions of a generally "undemocratic" content or implication-was much more difficult to comply with.

The American legal profession and the public at large have become thoroughly familiar with the progressive perversion of German law, paralleling the transformation of the Weimar liberal state (Rechtsstaat) -based on the concepts of equality before the law and protection of the citizen against arbitrary acts of the state and its officials-into the single party police state of Nazi totalitarianism. Numerous competent descriptions are available which this discussion cannot better and does not wish to repeat. ${ }^{40}$

37. Law No. 40 of Nov. 30, 1946 on "Repeal of the Law of January 20, 1934 on The Organization of National Labor," OG/CC, No. 12 at 229 (Nov. 30, 1946).

38. Law No. 45 of Feb. 20, 1947, OG/CC, No. 14 at 256 (Mar. 31, 1947).

39. Law No. 46 of Feb. 25, 1947, OG/CC, No. 14 at 262 (MFar, 31, 1947).

40. From among the voluminous material the following studies are selected:

On Nazi law in general: Fraenkex, The DuAL State (1941) (the most comprehensive monograph, extensively documented by court decisions [to 1938 inclusive] but less acceptable in its political conclusions); Loewenstein, Law in the Third Reich, 45 YALE L. J. 779 (1936) ; Roetter, The Impact of Nazi Law, [1945] W1s. L. REv. 516; Bonnard, Le Drott et l'Etat dans la DoctrnNe Nationale Socinlists (1936) ; Misiziewicz, Ie National Socialisare Allestand, ses Doctrmies et Realisatioiss (1937). See also Loewenstern, Hitleg's Gerarany 118 et seq. (rev. ed. 1944); Neonrast:, BEHEMTOTH (1941).

On civil law: Shartel and Wolff, Civil Justice in Gennany, 42 Mrrer. L. Rev. 863 (1944); Dickmann, An Outline of Nazi Cizil Lau, 15 MIss. L. J. 127 (1943).

On criminal law and proccdure: Wolff, Criminal Justice in Gcrmany, $42 \mathrm{~A}$ (rerr. L. REv. 1057 (1944) ; 43 MICr. L. Rev. 155 (1945); Kirchheimer, Criminal Lato in Nazi Germany, 7 Studies in Philosopry and Sochal ScIexce 44 (1939); Kirchheimer, Recent Trends in Germany's Treatment of Juzenile Delinqueney, 29 J. Cnns. L. \& CanrNoLOGY 362 (1938); Schwenk, Criminal Codification and Goucral Principles of Criminal 
The destruction of the Rechtsstaat resulted primarily from two ideological premises of the Hitler state. Its folkish doctrines required discrimination against racial minorities; and the single-party dictatorship, forever on the defensive against its internal enemies, necessitated discrimination against political nonconformists as well as preferential treatment of certain classes and groups dedicated to the maintenance of the regime. To these ends, the courts were converted into terror instruments of the state and the Party infiltrated into the judicial and administrative processes, the consequence being general public acceptance of the law and the courts as mere instruments of state coercion and party domination.

Contrary to popular misconceptions abroad, this process was accompanied, and in fact made possible, by an enormous output of law, and this it seems for two different reasons. On the one hand, the Nazis, faithful to the German positivist tradition, "legalized" arbitrariness by disguising their acts of political expediency as formal law, and manifested them in the statute books. On the other hand, totalitarianism is the successful attempt to bring most if not all private relationships under the guidance, direction and supervision of the state and of the single party identified with the state. The totalitarian technique consists in narrowing the range of autonomous private relations to the point where most of them are conducted under state control. From the juridical viewpoint totalitarianism is the supersession of private by public law. This process likewise required the promulgation of a formidable amount of formal legal norms because without them the judges and administrators, steeped in positivism, would have been unwilling to discharge their functions. In addition, preparation for and conduct of total war forced the regime into a completely controlled economy which likewise required definite legal rules. Consequently, the legislative mill of the Third Reich, unhampered by parliamentary restraints or other controls responsive to public opinion, was keyed up to an activity more frantic than anything known in the history of the legislative process. ${ }^{41}$

Denazification of German law and legislation, therefore, provided it was conceived as more than the merely mechanical elimination of pungently Nazi-flavored provisions, was a task of truly Justinian proportions. Strewn all over the statute book, they could not be repealed individually without a staggering amount of legal research.

For this very reason, Military Government Law No. 1 and Control Council Law No. 1 properly introduced a general "suspending clause"

Law in Germany and the United States-A Comparative Study, 15 TuLANE L. REv. 541 (1941).

41. The total output of legislative or regulatory enactments issued from 1933 to 1945 cannot be computed exactly. Those published in the official gazette of the Reich (Rcichsgestzblatt) alone reached five figures. 
which prohibits judicial or administrative application of discriminatory provisions contained in any German law. This was a clear order addressed to the German courts and it is obeyed by them faithfully. It is unthinkable that the courts, at least so long as they remain under Military Government supervision, ${ }^{42}$ will apply such forbidden provisions.

But the problem of overall legislative reform was much more complex because the entire legislation of the regime was permeated by its ideology. Without always being advertised by crude discriminations (which any judge may recognize as forbidden without much study), Nazi concepts had been carried into every legislative nook and cranny, and into legal fields of seemingly neutral character politically, such as corporation law, ${ }^{43}$ family law, ${ }^{44}$ insurance, cooperatives, patents, agriculture, and public health, to name only a few at random. It is true that none of the grandiose projects for the wholesale reform of the five basic codes which had been under preparation by the Nazi legal planners reached the statute books; but criminal law and procedure were amended almost beyond recognition, and even parts of the codes of civil law and procedure were subjected to reform ${ }^{45}$ although the civil law, which governs the legal relations of daily life, proved more Nazi-resistant than other fields.

\section{(4) The Strategy of Legislative Reform}

Legislative reform found itself on the horns of a dilemma. Unless the bulk of German law placed on the books since 1933 were subjected to a close scrutiny as to its latent Nazi content, German judges would either unquestioningly apply legal provisions often as Nazi-inspired as the palpably unsavory ones, or would themselves have to decide what laws to apply. They could hardly be trusted or expected to do this properly. ${ }^{46}$ Moreover, if they refused to apply such provisions, in many cases no legal decision at all would be possible. Had the official pro-

42. See Loewenstein, supra note 1 , at 438 et seq.

43. See Mann, The New German Company Law and its Baclegroumd, 19 J. Cosar. LEg. (3rd ser.) 220 (1937).

44. See Mankiewicz, German Law of Alimony Before and Under Nalional Socislism, 6 Law \& Contens. Pros. 301 (1939).

45. Important cases in point are the reform of the sections on marriage of the fourth book of the Civil Code by the law of July 27, 1938 (Gesetz sur Vcreinhcillichung des Rechts der Eheschliessung and Ehescheidung im Lande Österreicls and im ubrigen Rciehsgebiet), [1938] RGB1. I, 923 and the Judicial Procedure Reform Law (Bchannlnachtorg der Neufassung der Zivilprozessordnung) of Nov. 8, 1933, [1933] RGBI. I, 821. None of these, however, was wholly Nazi-inspired; in many respects they incorporated legitimate postulates of the legal profession of long standing. On civil procedure see Schopflocher, Civil Procedure: A Comparative Study of Some Princifal Features Under German and Anterican Law, [1940] WIS. L. Rev. 234; Cohn, New Regulations is the Gcrman Code of Cizril Procedure, 17 J. Coarp. LEg. (3rd ser.) 73 (1935).

46. See Loewenstein, stpra note 1 , at 433 et seq. 
nouncements on the occupation objectives in the field of law properly grasped the issue, they would have implemented their repeals and prohibitions-purely negative actions-by instructions to substitute democratic rules for Nazi rules.

Despite this omission, American Military Government lawyers were from the outset fully conscious that, if they wished "to restore to the German people the rule of justice and equality before the law," 47 their work would have to extend beyond the narrow range of the legal objectives outlined at Potsdam to an incisive legislative reform. Yet in the command elements confronted with the problem, the Control Council no less than the Zone Commanders, ${ }^{48}$ there was little agreement on the extent of legislative reform desirable and even less on the methods to be followed, the confusion being compounded by the divergent social and political ideals of the respective governments.

Long after the establishment of the Control Council in July, 1945, the disputes raged. Among adherents of extensive reform, two, or, rather, three schools of thought evolved. The most convenient approach suggested that the clock be put back, by one resolute stroke, to January 30,1933 . But to resort to the wholesale repeal of all legislation enacted thereafter was wholly impracticable. It could not have been done with retroactive effect, since numerous legal relationships established under Nazi law would have been deprived thereby of their legal basis. History knows of no restitutio in integrum. Moreover, this procedure would have deprived the German governments no less than the occupation authorities of the indispensable controls which collapse conditions required for all fields of social and economic life. Restoration of the pre-Nazi situation of a preponderantly liberal economy, based on free enterprise and its corollary, the widely used freedom of cartelization, was surgery to kill the patient.

In addition, a study of legal transformations since 1933 revealed that the Nazis had introduced many technical and substantial improve-

47. See Preamble to MG Law No. 1, OG/MG Issue A at 3 (June 1, 1946); MGR 5.100, (e) and 5.400.1.

48. Denazification of German law had been under advisement by various American governmental and military agencies long before the invasion, among them in Europe being the German Country Unit (of the SHAEF period) and the United States Group CC, organized in the late summer of 1944 to take its place in the future United States Zone of Occupation; see ZINK, op. cit. supra note 11, at 42 et scq. In Washington the problem was considered by the War Department and the Foreign Economic Administration. The author prepared in 1943 in the Department of Justice a plan for the "de-contamina" tion of German law." A semi-official group of former German lawyers and jurists in London submitted a comprehensive program to the British occupation authorities. Much of the preparatory material was inadequate and, because of departmental jealousies, wholly uncoordinated. A plan for legislative denazification properly prepared in advance would have been invaluable for the $\mathrm{CC}$ work and could have saved the American taxpayer much money. 
ments not derived from their ideological premises. This does not imply that their legislative technique was superior or equal to that of the Republic. On the contrary, legal positivism - characterized by adequacy of legal means for the objectives of social control and consonance of verbal formulation with the purposes-had been superseded by political flamboyancy. In consequence, the habitual solid draftsmanship and logical continuity of German laws had given way to ambiguous language and a maze of amendments, cross-references and incongruities of legislative texts. Nonetheless, in many fields the Nazi regime had created new legislation which was sound and merited being preserved in a democratic society. Consequently, total repeal was ruled out except for elimination of the "political" legislation of the regime.

The second school of thought, therefore, advocated the procedure of individualization. Each legislative topic, and within it, each enactment, should be analyzed as to its Nazi content. If focused merely on the flagrant Nazi provisions entailing discrimination, the task though timeconsuming seemed easy enough. In practice, howerer, this method involved systematic research into the entire body of German legislation since 1933. More often than not the Nazi inspiration of a specific enactment, or parts thereof, became recognizable only when verified by its judicial or administrative application. Moreover, in some cases it was found that objectionable legislative policies either antedated the Nazis, or might have been justified in the different political environment at the time of enactment. ${ }^{49}$ Should these likewise be repealed?

Even after the technique of individualization had been accepted, new difficulties arose. In many cases, repeal required replacement of the stricken Nazi provision or provisions by another rule or set of rules since the situation could not be left without appropriate regulation. Here the third school of thought received its cue. If Nazi legislation had to be replaced by other regulations, would it be sufficient to revive those existing before 1933 (provided any existed) or should such improvements of technique or substance be incorporated as were suggested by the home experiences of the occupying powers? Disciples of this school admitted denazification to be the primary objective, but urged that the opportunity not be missed to give the Germans technically improved and if possible more democratic laws, modernized beyond $1933 .{ }^{50}$ And if the answer was in the affirmative, who should be the

49. Examples are the tax exemptions granted prolific families and the preferential treatment accorded former soldiers in obtaining state employment.

50. Section 55 of the Nazi marriage law of 1938 may serve as illustration. It permitted divorce, without guilt of either marriage partner, on the ground of incompatibility. Before 1938, it was common among the most respectable lawyers to resort to collusive practices in order to obtain separations, for, under the Code of 1900, incompatibility vas not recognized as a ground for divorce. The courts willingly played the game by aceepting fictitious evidence. Mechanical return to the pre-1933 situation would have deprived 
legislator? Should German law be ameliorated by the occupying powers on behalf of the Germans, or should reforms be left to a German government legislating for Germany as a whole?

At this point it may be asked why this gigantic task was not assigned from the start to the Germans who after all know their law better than foreign lawyers. The answers are three. First, the skeleton staffs in the Ministries of Justice of the Länder in the United States Zone (and similar departments in the other zones) did not have the required manpower. Second, there was-and more than two years after the collapse there still is-no German agency operating for Germany as a whole in the legislative field. Third, among the German Länder, now numbering (with Berlin) seventeen, ${ }^{51}$ there exists as yet no machinery for coordination; to bless Germany with seventeen different marriage laws, or codes of criminal procedure, would confer no benefit on a state accustomed to legal unity, though perhaps not disturbing to lawyers from a country with forty-nine different legal systems. Moreover, the situation was so urgent that the task of legislative reform was thrust on the conquerors' limited staff of experts in German law. ${ }^{52}$

After months of discussion within the American element and among the four powers in the Control Council, the plan to denazify all German legislation by the individualized procedure won the battle. But it proved to be a Pyrrhic victory. A mere handful of competent Military Government lawyers, venturing into the morass of Nazi law, by themselves actually undertook denazification of individual legislative sub-

the Germans of a serviceable means of peacefully dissolving irreparably disrupted marriages. On the other hand, the provisions though outwardly devoid of any Nazi inspiration-as a matter of record the legal profession for a long time had advocated the innovation-was misused by Nazi courts to discriminate against wives in order to have marriageable partners available for procreation. The proper solution in Section 48 of the new Marriage Law of the CC, No. 16 of Feb. 20, 1946, OG/CC, No. 4 at 77 (Fcb. 28, 1946) was to redraft the provision in such a way that its usefulness for the public in general was preserved and partiality in its application excluded.

51. In the American Zone are the Länder Bavaria, Württemberg-Bade, Hesse and Bremen; in the British Zone are the Länder North Rhine-Westphalia and Lower Saxony, the Province of Schleswig-Holstein and the Free City of Hamburg; in the French Zone (not counting the Saar Basin which is economically incorporated into metropolitan France) are the Länder Rhineland-Palatinate, Württemberg-Hohenzollern and South Baden; in the Soviet Zone are the Province of Saxony-Anhalt, and the Länder of Saxony, Thuringia, Mark Brandenburg and Mecklenburg-Vorpommern.

52. At various times AMG considered recruitment of a staff of German lawyers who, under the direction of the Legal Division-after midsummer 1946 a special section on German Law Reform was established within its Legislation Branch-would undertake denazification and demilitarization of all legislation. The project did not prove feasible because the Germans neither were prepared to denazify as thoroughly as desired nor could they be allowed to interpret the occupation policies. It may be noted that both the Soviets and the British put more store by the ability of their German advisors. The Soviet element relied heavily on German experts of the German Central Administration for Justice in the Soviet Zone in Berlin which, under the leadership of Dr. Eugen Schiffer, 
jects selected at random for either quadripartite or zonal treatment, ${ }^{53}$ while the Legal Directorate of the Control Council ${ }^{54}$ merely discussed -and disagreed on-program and methods. No agreement existed among the powers as to subjects appropriate to Control Council or individual zonal legislation, nor was any Control Council priority system devised. Thus, in the initial period, quadripartite deletion and replacement of Nazi legislation were entirely on a hit-or-miss basis. What was done depended on the ability of the national element sponsoring a proposal to convince the other elements of its urgency and expediency, a process often made even more difficult by political objections impeding consideration of matters of seemingly merely technical character.

\section{(5) The Quadripartite Committee on the Reform of German Law}

When it was realized that by this chaotic method the Control Council could not cope with the task of legal denazification, a more systematic approach was sought by the establishment of the quadripartite German Law Revision Committee, the first meeting being held on March 21, 1946. The Committee's objective 55 was "to examine German legislation and to make recommendations to the Legal Directorate for the elimination from it of Nazi laws and for the substitution where necessary of appropriate provisions." This program, going beyond the previously formulated occupation policies on legislative reform, evidently was intended to contribute its share to the larger Potsdam objectives of decentralization, democratization and demilitarization. This may be gathered from the program's stigmatization of all provisions relating to the NSDAP; provisions inspired by the Nazi doctrines of race, blood and soil, or by the leadership principle (which, for example, had infiltrated corporation law); provisions exacting unduly harsh pun-

a prominent jurist and former Minister under the Republic, had become a sort of Ministry of Justice for the entire Soviet zone. The British likewise utilized to good advantage a permanent group of former German legal experts in London to whom all CC proposals (and presumably those affecting the British Zone as well) in the legal field vere referred. Whether the French have a similar organization in their zone is not known to the author.

53. The most notable accomplishment in the American Zone is the revised Code of Criminal Procedure, uniformly introduced, however, by land legislation and not as an MG enactment.

54. Directorates are quadripartite CC staff groups composed of the chicfs of each government's functional divisions. Nine are at present organized under the Four Power Statement on "Control Miachinery in Germany" of June 5, 1947, (3) OG/CC, Supp. No. 1 at 10 (April 30, 1946) : Armed Forces, Economics, Finance, Transport, Mranpower, Internal Affairs and Communications, Civil Administration, Legal, Displaced Persons and Prisoners of War. See also Special Report of the Mfilitary Governor, United States Zone, op. cit. supra note 6 , at 3.

55. See Rep. No. 14, Legal and Judicial Affairs, Cusulative Review, Sept. 20, 1946, p. 4. 
ishments; provisions expressive of anti-democratic doctrines; those implementing the centralization policies of the Nazi regime; provisions unduly restricting individual liberties, especially those abridging guarantees or rights of the individual against the state or agencies of public administration; provisions promoting the spirit of militarism, and those related to the organization and activities of the German armed forces. ${ }^{60}$ After months of discussion, an operational plan for the entire field of legislative denazification was achieved which provided for farming out legal topics to each of the four powers. ${ }^{57}$ The distribution seemed a fair allocation of the heavy load. Each power was free to determine the procedure for its share in the work.

The Americans considered using as subcontractors the Ministries of Justice of their Länder (which in turn were requested to form legislative reform committees of their own), the law faculties of the universities in the zone and individually enlisted German experts. The Legal Division of American Headquarters in Berlin retained general direction and supervision through the German Law Revision Section of the Legislation Branch, established by midsummer of 1946.

As had been skeptically anticipated, the plan proved wholly unworkable. Its completion would have taken many years. Never could dispersal of work among four powers, disagreeing on political and social aims, and among countless uncoordinated German subagencies be an adequate substitute for a central Ministry of Justice or a central parliamentary body. The plan also transcended the capacities of the quadripartite legal staffs because the replacement of unsuitable provisions calls for expert knowledge on practically all aspects of German life which, if at all, could be obtained only in cooperation and consultation with the other functional directorates of the Control Council.

Consequently, during 1947 a new plan was developed under which

56. It is a curious illustration of the haphazard methods of the CC that while actual demilitarization measures were going full blast the formal abolition of the German Wehrinacht had been overlooked; this was done belatedly by CC Law No. 34 of Aug. 20, 1946, OG/CC, No. 10 at 172 (Aug. 31, 1946).

57. The details of distribution are as follows:

United States: (1) cultural affairs; (2) police and public safety; (3) public health; (4) youth; (5) Wehrmacht; (6) war damages; (7) public international law; (8) private international law;

United Kingdom: (1) constitutional questions; (2) public administration; (3) civil service; (4) social legislation; (5) crafts and industries, mines and mineral resources; (6) shipping and waterways;

France: (1) trade (including banking, currency and foreign exchange) and price control; (2) food and agriculture (including forestry, game and fisheries); (3) budget (public funds and expenditures); (4) taxation (including procedure), direct and excise taxes, customs duties; (5) communications (including roads, railways and air);

Soviet Union: (1) organization and administration of courts and legal personnel (including training); (2) civil procedure; (3) labor law; (4) labor supply; (5) social insurance; (6) social relief. 
the entire body of law will be analyzed to determine whether individual enactments require outright and complete repeal, partial abrogation, or amendment, and whether such legislative reforms should be undertaken by the Control Council or by the zonal authorities. Simultaneously, it will be decided which functional directorate, provided a matter comes under Control Council jurisdiction, will undertake the redrafting, while the Legal Directorate will confine itself to reforms of law in the narrow technical scale. This scheme at long last seems to realize that a precise line of demarcation must be drawn between Control Council and zonal jurisdiction.' It seems also understood that the actual work of redrafting, upon approval of the plan by the Legal Directorate and the zonal administrations respectively, will be undertaken by the Germans themselves.

At the time of this writing it appears ${ }^{89}$ that the program-as ambitious in scope as it is unwieldy in execution-has not yielded tangible results in terms of actually placing major pieces of quadripartite legislation on the books. At best its work is preparatory to this end. But the German Law Revision Committee serves a useful purpose by functioning as a sort of coordinating agency for the legislative proposals submitted to the Legal Directorate by the individual powers and also as a technical clearing house for proposals coming before it from other functional branches. ${ }^{59}$ Compared with the former casual method of initiating quadripartite legislation, this may be a definite improvement of procedure.

In retrospect, doubts may be justified as to whether any quadripartite legislative agency, even if its work were more systematized and better planned from the beginning, could substitute for a common German agency charged with over-all legislative coordination. If, in view of the organizational difficulties and political divergences on the quadripartite level, German law reform devolves by default on the

58. Efforts of the author to obtain adequate information on the recent activities of the Committee on the Reform of German Law proved unariling. It secms that for the time being the Committee is investigating matters of law in the narrow sense esclusively, recommending that individual provisions or entire enactments deemed obnoxious be repealed, or that no action be taken on them. But who is to undertake the actual legislation (the.CC, the Zonal Commanders, the German Land agencies, or a future German gorerriment?) could not be ascertained.

59. According to private information, the Committee, for example, was charged by the Legal Directorate with drafting law on missins persons, repealing certain veterinary laws of the Nazi period and devising regulations preventing banls from engaging in stock exchange transactions. It also revised certain provisions of the code of civil procedure and redrafted certain sections of the civil code dealing with legitimacy. Amons its proposals is one for the regulation of examinations of candidates for judicial offecs (which prior to Hitler had been under the jurisdiction of the Läsder within the general frame of the Judicature Act [Gerichtsoerfassungsgesetz] of 1877). The Committee is also being used for amendments of CC laws previously enacted. 
German authorities, further doubts may be in order whether the important task will not be postponed ad Calendas Graecas.

\section{Military Government and the Legislative Process}

\section{(I) Jurisdictional Structure}

The legislative process in present-day Germany under the occupation may be explained as a system of concentric circles of jurisdiction. Of these the most extensive is the quadripartite enactment of the Control Council, applicable to all four zones and Berlin. ${ }^{60}$ Under the Potsdam agreement, it should here be noted, the occupying powers are pledged to treat Germany "as a single economic unit," 61 and to reach common decisions on the chief questions affecting Germany as a whole. ${ }^{62}$ No clearer delineation of the powers of the Control Council has ever been issued.

Moving toward the center there follows next zonal legislation issued by the zone commanders and binding all territorial subdivisions comprised by the zone. Exercising jurisdiction co-extensive with that of the zone commanders are the German zonal authorities established by them-in the American zone the Länderrat, and such similar agencies as may exist in other zones. Within the zones, the Land governments have authority to legislate, depending upon the extent of independence granted by the occupying power. The chart is further complicated in that, with the merger of the American and British zones, the bizonal German agencies are authorized to legislate in economic and related matters with binding force for the two merged zones, thus constituting an intermediary legislative layer between the quadripartite Control Council and the German zonal authorities.

Before, however, reviewing the legislation actually enacted, two of the technical aspects in a country administered by foreign occupation authorities warrant some consideration because of their practical implications.

60. Berlin is subdivided into four parts, or sectors, each one assigned to one of the Four Powers, under the combined MG authority of the quadripartite Kommandatura. See Four Power Statement of June 5, 1945, OG/CC, Supp. No. 1 at 11. On the political structure of the Berlin government see Special Report of the Military Governor, United States Zone, March 15, 1947, op. cit. supra note 6, at 14. Enactments issued by AMG for its zone are, as a rule, applicable also to the American sector of Berlin. See Appendix of OG/MG, Issue C at 15 (April 1, 1947) ; Issue F at 16 (Oct. 31, 1947). The situation in Berlin is particularly complex in that life in each sector is governed, in addition to the CC and Konmandatura enactments, by the zonal legislation of the power under whose jurisdiction the sector finds itself and by laws passed by the City Magistrat (municipal government).

61. III A (14), OG/CC, Supp. No. 1 at 15 (April 30, 1946).

62. III A (2)-(10), id. at 14-5; cf. Four Power statement of June 5, 1945 "On Control Machinery in Germany," id. at 10. For the special fields in which it was desired to establish agencies for the entire country, see note 18 supra. 


\section{(2) Translations}

Addressees of Military Government enactments, whatever their source, are the Germans, their authorities, practitioners and the public at large. Yet all proclamations, laws, orders, ordinances, directives and instructions of the Control Council are issued in the English, French and Russian languages. A German translation is issued whenever the measure is "designed to regulate or govern the people of Germany, or German officials and agencies," but only the three Allied languages are considered official. The validity of any enactment does not depend upon issuance or publication in German. German translations published together with official texts are "for convenience only." c3

The paramount importance of the issue at first was not realized by the Control Council. The Germans could hardly be expected to obey and apply enactments drawn up in a foreign language. It proved equally impracticable to let the Germans rely on a translation of their own ${ }^{64}$ even though it might be an "official" one, issued by a govern-

63. See CC Directive No. 11 of Sept. 22, 1945, OG/CC, No. 3 at 39 (Jan. 31, 1946) Arts. I and IV. Ordinance No. 3 (SHAEF), OG/MIG, Issue $A$ at 71 (June 1, 1946) decreed that English and French be the official languages for the respective areas. Every person affected by an MG enactment is held for the fulfillment of its terms as expressed in its official text, and it is not a defense that the terms of the official document are not understood, or that any translation thereof into German was not an accurate translation of the official text; see also MG Law No. 4 (as amended), id. at 17, Art. II (5), according to which in case of any discrepancy the English text shall prevail over the German text published in the Military Government Gazette. However, when Ordinance No. 14 (effective June 10, 1947) on "Production, Allocation and Distribution of Goods and Raw Materials," dealing with the economic powers of the Executive Committee for Economics (established in pursuance to the economic merger of the American and British Zones), was published (OG/MG, Issue $\mathrm{E}$ at 6 (June 1, 1946)), it was found advisable, in vicw of the technically complicated subject matter, explicitly to invalidate the superiority of the English text and attach the same authenticity to the German text. See $\S 43$. In this case the English text reads rather as a translation of the German. The same priority was granted the German text of the important MIG Law No. 59 (effective Nov. 10, 1947) on "Restitution of Identifiable Property." OG/AIG, Issue G at 1, Art. 94.

64. This is particularly important in the case of CC legislation. A translation published by a German authority was apt to differ from the translation of the same cnactment published in other zones if based on an official text in another language. Such divergences resulted in conflicting interpretation and application by the courts. For example, the unofficial translation, by the Berlin Magislrat, of CC Law No. 1 of Sept. 20, 1945, OG/CC, No. 1 at 6 (Oct. 29, 1945) used, as equivalent to the English term "repeal" or "abrogation," the German word "uriderrufen" (revole) instead of "a:uficben." Thereupon, the Berlin Kammergericht (Court of Appeals, decision of Dec. 21, 1945, File No. 2.W.445 ) interpreted the article to the effect that rights that had existed prior to the passage of the Nazi law are considered restored or revived, in conformity with German legal theory which assumes that when a legal provision is "revoked," its effect is ex tume, while when "repealed" it operates ex nunc. Consequently, CC Law No. 55 of June 20, 1947, on "Repeal of Certain Provisions of Criminal Legislation," Article II, OG/CC, No. 16 at 284 (July 31, 1947) explicitly stated that "Nothing in this Law shall revive any legislation which was abrogated by any provision or enactment repealed by the Law." 
mental authority. From the beginning, therefore, the text in the foreign language was accompanied by a translation. While few complaints arose from such translations of United States zonal measures, those accompanying Control Council legislation were, at least in the initial stage, incompetent, unreliable, and in conflict with German legislative terminology.

After considerable damage had been done, a quadripartite Translation Committee, attached to the Legal Directorate, took charge of the "unofficial" German translations accompanying "official" texts, But the inherent technical difficulties continued. Even though the phrasing might have been clear beyond reasonable doubt in any one of the three official languages - and those participating in any quadripartite group will readily agree that finding an expression appropriate in all three official languages at times is difficult enough-equal intelligibility when translated into German was by no means assured. Divergences were due, in part, to the difficulty of finding a fully adequate equivalent in German, and in part to the inexperience of the foreign draftsmen in German legal terminology, particularly when quadripartite legislation had to be grafted on existing German law. The Control Council lawyers were apt to conceive their objectives in terms of their own legal background. After much trial and error, however, a workable solution was adopted whereby a translation is issued by the quadripartite Translation Committee and is considered "official" for all purposes except that where authenticity is challenged it must yield to the text in the language of the occupying powers.

\section{(3) Notice}

Application of legislation further depends on its being properly made public. Formerly in Germany subscribers had obtained the official law bulletin of the Reich (Reichsgesetzblatt) and the corresponding gazettes of the Länder from the post office at cost within a day or two after publication. In occupied Germany, where the multiplicity of the sources of legislation all the more requires prompt service, the breakdown of communication, the scarcity of paper and the lack of printing facilities make speed almost impossible.

American Military. Government initially ordered that "legislation which is addressed to the general public will be posted in appropriate places and will be published in newspapers and official gazettes." of But posting proved impractical; considering the length of some enactments and the posters' exposure to wind and weather, while newspaper texts were unreliable. Gazettes are now published by both the Control Coun${ }^{c i l}{ }^{66}$. and American Military Government. ${ }^{67}$ But they are printed in

65. MGR.5.207.

66. Directive No. 11 of Sept. 22, 1945 on "Official Languages and Publication of Legislation," OG/CC, No. 3 at 39 (Jan. 31, 1946).

67. Authorized for both OMGUS Headquarters and the Land MG Offices; see 
limited editions and are invariably issued months after the enactments contained have gone into force. At the end of 1945 the Länder began to issue their own official gazettes at irregular intervals but likewise with so much delay that even German legislation more often than not became effective long before the public was aware of it. Recently, private collections of the loose leaf variety have begun publication. But the situation, hardly conducive to legal security, remains unsatisfactory. ${ }^{63}$

Within the jurisdictional framework and subject to the technical difficulties here set out, the occupying authorities have to greater or lesser extents endeavored to reform German law. An attempt will now be made to discuss the law-making process of the Control Council, the American zonal authorities and the German agencies and their results to date.

\section{Control Council Legislation}

\section{(I) Form}

In legislating for Germany as a whole the Control Council may use any of the following techniques: (a) outright repeal of an individual and specifically named enactment; ${ }^{c 9}$ (b) abolition of an institution by repealing the legislation on which it is based; ${ }^{70}$ (c) partial repeal; used particularly when an enactment is considered unobjectionable provided the patently Nazi provisions are removed; ${ }^{71}$ (d) amendment of legislation otherwise remaining in force; rather rarely employed because of the intrinsic difficulties of grafting quadripartite principles on German law; ${ }^{72}$ (e) substitution; employed when the elimination of Nazi content

Amendment to Law No. 4 of July 14, 1945, OG/MG, Issue A at 17 (June 1, 1946); MGR 5.215.1 and 5.215.2; 5.221.1 and 5.221.2 in Change 1.

-68. For example, since the official text of the Miarriage $\mathrm{Law}_{2}$ of the CC, No. 16 of Feb. 20, 1946, OG/CC, No. 4 at 77 (Feb. 28, 1946) entering into force on Mrarch 1, 1946, was unobtainable, the courts for months thereafter continued to apply the $\mathrm{Nazi}$ law though it had been officially repealed by the CC law.

.69. Examples are the various enactments enumerated in CC Law No. 1, Art. I, OG/CC, No. 1 at 6 (Oct. 29, 1945), and the corresponding statutes mentioned in 21 G Law No. 1, Art. I, OG/MG, Issue A at 4 (June 1, 1946) ; CC Law No. 49 of March 20, 1947 on "Repeal of Reich Law of July 14, 1933 concerning the Constitution of the German Evangelical Church," OG/CC, No. 14 at 265 (Mirarch 31, 1947).

70. Examples of CC legislation are Laws No. 34 of Aug. 20, 1946 on "Dissolution of the 'Wehrmacht," OG/CC, No. 10 at 172 (Aug. 31, 1946); No. 2 of Oet. 10, 1945 on "Termination and Liquidation of the Nazi Organizations," OG/CC, No. 1 at 19 (Oct. 29, 1945) ; No. 9 of Nov. 30, 1945 on "Seizure of Property Owned by I. G. Farbenindustrie A.G. and the Control Thereof," OG/CC, No. 2 at 34 (Nov. 30, 1945).

71. CC Law No. 11 of Jan. 30, 1946 on "Repealing of Certain Provisions of the German Criminal Code," OG/CC, No. 3 at 55 (Jan. 31, 1946), and CC Law No. 55 of Jume 20, 1947 on "Repeal of Certain Provisions of Criminal Legislation," Art. I (1) (3) (8) (12), OG/CC, No. 16 at 284 (July 31, 1947).

- 72. An example is CC Law No. 13 of Feb. 11, 1946 on "Amendment of Property" 
cuts so deeply into the existing text that the entire law has to be rewritten; the existing enactment is formally repealed but in individual cases much of it is incorporated into the new text; ${ }^{73}$ (f) new legislation; this constitutes the bulk of Control Council legislation. In this latter case the Control Council enactment may regulate any situation the occupation objectives may require, particularly political matters in the widest sense of the term, such as democratization, decentralization, demilitarization and denazification. ${ }^{74}$ Conflicting German legislation, which loses validity anyway by vis facti, sometimes is revoked explicitly, sometimes not.

Control Council legislation may be issued in any of the following forms: ${ }^{75}$ (a) proclamations, "to be issued to announce matters or acts of special importance to the occupation powers, or to the German people, or both"; (b) laws, "to be enacted on matters of general application imposing requirements on the German people"; (c) orders, issued "in cases where no formal laws are used"; (d) directives, "to communicate policy or administrative decisions of the Control Council"; the line of demarcation between laws and directives is by no means precise; next to laws, directives constitute the most important quadripartite legislative actions; (e) instructions, "to be issued in cases where the Control Council wishes to impose requirements direct (sic) upon a particular authority." Proclamations, laws and, occasionally, orders are signed by the Control Council itself; orders may also be signed by the Coordinating Committee ${ }^{76}$ which regularly signs directives and instructions.

For a long time, the different forms were used almost interchangeably. Early in 1947, however, the relationship between content and form was defined with greater precision. ${ }^{77}$ Now, legislative action is

Tax Laws," OG/CC, No. 4 at 71 (Feb. 28, 1946); the basic structure of the German Vermögenssteuergesetz remained unaffected.

73. CC Laws No. 16 of Feb. 20, 1946 on Marriage, OG/CC, No. 4 at 77 (Feb. 28, 1946) ; No. 45 of Feb. 20, 1947 on "Repeal of Legislation on Hereditary Farms," etc. OG/CC, No. 14 at 256 (March 31, 1947). An illustration on the zonal level is the Rechtsanzultsordnung ("Lawyers Code") enacted uniformly for the United States Zone by the Länderrat (for Bavaria : see [1937] GVB1.371).

74. Pertinent illustrations are: CC Laws No. 10 of Dec. 20, 1945 on "Punishment of Persons Guilty of War Crimes, Crimes against Peace and against Humanity," OG/CC, No. 3 at 50 (Jan. 31, 1946); No. 23 of April 10, 1946 on "Prohibition of Military Construction in Germany," OG/CC, No. 6 at 136 (April 30, 1946); No. 33 of July 20, 1946 on "Census of the German Population," OG/CC, No. 9 at 166 (July 31, 1946).

75. See Directive No. 10 of Sept. 22, 1945 on "CC Methods of Legislative Action," OG/CC, No. 3 at 38 (Jan. 31, 1946).

76. The Coordinating Committee, a permanent committee on the second highest level of the CC, is composed of one representative of each of the four commanders-in-chief; see Four Power Statement of June 5, 1945 on "Control Machinery in Germany," OG/CC, Supp. No. 1 at 10 (April 30, 1946), and $Z_{\mathrm{INK}}$ op. cit. supra note 11, at 70.

77. Directive No. 51 of April 29, 1947 on "Legislative and Other Acts of the CC," OG/CC, No. 15 at 279 (May 31, 1947). 
issued in the form of either a proclamation, a law, or an order, the classification being determined by the Legal Directorate. Only laws and orders may contain penalty clauses. Directives may prescribe penalties to be adopted by the Zone Commanders in the implementing measures which they promulgate.

\section{(2) Drafting}

Initially, legislative proposals for enactment by the Control Council were drafted, as a rule, by the functional quadripartite directorate originating them. Because of frequently incompetent drafting and lack of integration with existing or planned legislation, this method proved unsatisfactory and the entire drafting procedure was centralized in the Legal Directorate, ${ }^{78}$ the only group within the Control Council possessing adequate legal personnel. Proposals of any directorate which may require legislative action are presented initially to the Control Council or the Coordinating Committee in plain language and not in legal terminology. Upon approval the proposal is referred to the Legal Directorate for legal drafting. Proposals of a simple character may be submitted by the initiating directorate in completed legislative form to the Council or the Coordinating Committee but the Legal Directorate must be consulted on any legal aspects.

To handle this burden, the Legal Directorate established a quadripartite Legislative Drafting Committee to give the proper legal form and language to all proposed policy directives whatever their content or subject matter and regardless of the originating directorate. At first sight this may seem a rather subordinate task easily accomplished by legal technicians. It proved to be an assignment of considerable difficulty and significance. More often than not, a proposal, on which the functional directorate seemingly had reached quadripartite agreement, revealed hidden and unresolved controversies when its conversion into legal form was attempted-perhaps new proof of Doctor Faust's wisdom that "Im Anfang war das Worl" ("In the beginning was the word"). By necessity the Legislative Drafting Committee immediately attained a position of cardinal importance in the Control Council machinery. Throughout, its meetings have been veritable seminars in semantics for the participants who have to harmonize the verbalistic attitudes of four powers, using three different languages, and to make the common legislative intent intelligible to the Germans. When, however, the Committee's first-class specialists acquired familiarity with the peculiarities of the national techniques used by the others, the Committee in due course became a smoothly and efficiently operating team.

78. CC Directive No. 13 of Oct. 5, 1945, MIGR 2.161.12 (the Directive is not published in the $O G / C C$ ). 


\section{(3) Topical Survey of Legislation Enacted}

For an appraisal of quadripartite activities it should be clearly understood that the Control Council has a dual function: it is the executor of the occupation policies laid down at Potsdam, and, no less notable, it is presumed to act in the place of the non-existing central German government. It is certainly true that the supreme quadripartite authority conducts itself dictatorially without in any way consulting the people or being responsible to them. But the dictatorship is benevolent and, within the limits of human nature, free from vindictiveness. Even though its methods are frequently disciplinarian, it professes that the democratic future of its ward is its primary concern.

In a rudimentary form, then, at least as long as the Control Council is able to legislate for Germany as a whole, Germany possesses an -agency which approximates a central government. ${ }^{79}$ Council legislation is applicable to the four zones much in the same way as in the federal state the enactments of the national or federal government take precedence over those of the territorial subdivisions. The importance of the Council for the maintenance of legislative unity in many fields should not be minimized. So much attention is being paid to the fact that to date no central German agencies, not even those authorized by the Potsdam Declaration, ${ }^{80}$ have been established, and so much is being made of the disagreements among the four powers on general policies or individual measures-which undoubtedly exist-that the erroneous impression is created of an organization constantly divided against itself and incapable of joint action for Germany as a whole.

The following summary of legislation enacted up to January 31 , $1948,{ }^{81}$ will testify to the wide compass of activities the Council has undertaken in its double capacity as the joint body representing the

79. This is the assumption underlying the Four Power Statement of June 5,1945 on "Control Machinery in Germany," OG/CC, Supp. No. 1 at 10 (April 30, 1946) to the effect that "the CC ... will reach decisions on the chief questions affectint Germany as a whole," a formula repeated by the Potsdam Declaration (III A (2)) id. at 13, 15, that, "so far as is practicable there shall be uniformity of treatment of the German population throughout Germany." The subsequent (III A (3)) enumeration of the "purposes of the occupation" roughly equals the catalogue' of fields which should be regulated uniformly for all Germany. The crux of the matter, however, lies in the fact that while CC legislation overrides zonal legislation there is no legal obligation of the CC to deal with these fields, nor has the $\mathrm{CC}$ exclusive jurisdiction over the enumerated topics, with the result that zonal legislation may permanently occupy a field originally destined for the CC.

80. These are, under III A (9) (IV), OG/CC, Supp. No. 1 at 13, 15 (April 30, 1946), "particularly in the fields of finance, transport, communications, foreign trade and industry."

81. The Official Gazette of the CC is available to No. 18 (Jan. 31,1948 ) inclusive. The survey is not exhaustive; in particular the material concerning the internal organization of the CC is omitted. 
interests of the occupation powers and as the central legislative authority for Germany as a whole. Legislation may be classified along the following topical lines:

(a) Demilitarization in the widest possible sense: that is, physical disarmament-relating either directly to the establishment and the military installations of the Wellrmacht, or indirectly to the military potential - and ideological or moral disarmament, intended to eliminate permanently the traditions and spirit of militarișm from the social, political and intellectual life of the Germans. ${ }^{62}$ Under this heading

82. In this and the following notes the enumeration without being chronological follows the order of publication in the Official Gazette. Order No. 1 of Aug. 30, 1945 "Prohibiting the Wearing of Uniforms by Former Mfembers of the German Armed Forces," OG/CC, No. 1 at 5 (Oct. 29, 1945); Law No. $S$ of Nov. 30, 1945 on "Elimin2tion and Prohibition of Military Training," OG/CC, No. 2 at 33 (Nov. 30, 1945); Directive No. 16 of Nov. 6, 1945 on "Arming of the German Police," OG/CC, No. 3 at 42 (Jan. 31, 1946) (the German police is limited to non-automatic weapons of non-German manufacture); Directive No. 18 of Nov. 12, 1945 on "Disbandment and Dissolution of the German Armed Forces," id. at 43; Directive No. 22 of Dec. 6, 1945 on "Clearance of Minefields and Destruction of Fortifications, Underground Installations and Military Installations in Germany;" 15 GR 23.161.22; Directive No. 28 of April 26, 1946 on "Reports on Disposal of German War Material in Germany;" IIGR 23.161.23; (the last two Directives were not published in the Official Gazette).

Directive No. 23 of Dec. 17, 1945 on "Limitation and Demilitarization of Sport in Germany," OG/CC, No. 3 at 49 (Jan. 31, 1946); Order No. 2 of Jan. 7, 1946 on "Confiscation and Surrender of Arms and Ammunition," OG/CC, No. 6 at 130 (April 30, 1946); Law No. 23 of April 10, 1946 on "Prohibition of Mfilitary Construction in Germany," id. at 136; Law No. 25 of April 29, 1946 on "Control of Scientific Research," id. at 138, with amendment of Nov. 12, 1946, OG/CC, No. 12 at 227 (Nov. 30, 1946) (see also MIGR Title 27) ; Order No. 4 of Miay 13, 1946 on "Confiscation of Literature and Material of a Nazi and Militarist Nature," OG/CC, No. 7 at 151 (Mioy 31, 1946), with amendment of Aug. 10, 1946, OG/CC, No. 10 at 172 (Aug. 31, 1946).

This last enactment was one of the most controversial ever issued by the $\mathrm{CC}$; it requires the removal from all bookstores, public and school libraries of all material containing Nazi propaganda or contributing to military training or education. Prohibited mzterial must be separately assembled and kept inaccessible to the Germans. The original injunction to destroy it-the CC equivalent of the "burning of the books" by the Naziswas successfully contested by at least two of the occupying powers. The magnitude and futility of the undertaking may be gathered from the fact that a Sorict-sponsored catalogue of outlawed publications (Liste der auszusondernden Liferatur, Berlin 1946) lists more than fifteen thousand individual items.

Directive No. 30 of May 13, 1946 on "Liquidation of German Mfilitary and Nazi Memorials and Mruseums," OG/CC, No. 7 at 154 (May 31, 1946); Law No. 34 of Aug. 20, 1946 on "Dissolution of the Welmrnacht," OG/CC, No. 10 at 172 (Aug. 31, 1946), to all intents and purposes the most important in this class, dissolving the organizational structure of the Wehrmacht and making its reconstitution or maintenance in whatever form illegal; Directive No. 38 of Oct. 12, 1946 on "The Arrest and Punishment of War Criminals, Nazis and Militarists and the Internment, Control and Surveillance of Potentially Dangerous Germans," OG/CC, No. 11 at 184 (Oct. 31, 1946) ; Directive No. 37 of Sept. 26, 1946 on "Limitation of Characteristics of Ships other than Fishing and Pleasure Craft Left to the Peace Economy of Germany," id. at 180; Directive No. 44 of Now 4, 1946 on "Limitation of Characteristics of Fishing Craft Left to the Peace Economy of 
may also be listed the extirpation of Prussia as a state..$^{83}$ Moreover, since modern war is primarily dependent on the economic potential of a country, the destruction of the organization of I. G. Farbenindustrie, the huge octopus of industrial concentration which had contributed much to the preparation and execution of Nazi aggression, may also be classified among the measures serving demilitarization. ${ }^{84}$

(b) Denazification likewise is conceived by the Council in the widest sense of the term. Primarily it extends to the prohibition and dissolution of the National Socialist Party and its affiliated and supervised organizations, and the seizure of its vast economic assets. But, as in the field of demilitarization, denazification aims also at the elimination from German social, public, intellectual and economic life of Nazi influence and spirit wherever it manifested itself in the past or could emerge again in the future. Enactments issued for this purpose are in part identical with those directed against the recrudescence of militarism. ${ }^{85}$

Germany," OG/CC, No. 12 at 224 (Nov. 30, 1946); Directive No. 45 of Nov. 9, 1946, on "Limitation of the Technical Characteristics of German Pleasure Craft," id. at 225; Law No. 43 of Dec. 20, 1946 on "Prohibition of the Manufacture, Import, Export, Transport and Storage of War Materials," OG/CC, No. 13 at 234 (Dec. 31, 1946).

83. Law No. 46 of Feb. 25, 1947 on "Abolition of the State of Prussia," OG/CC, No. 14 at 262 (March 31, 1947).

84. Law No. 9 of Nov. 30, 1945 "Providing for the Seizure of Property Owned by I.G. Farbenindustrie," OG/CC, No. 2 at 34 (Nov. 30, 1945). The Germans, at first incredulous that the smashing of the Farben concern was meant in carnest, continued to trade in its stocks even after the formal dissolution so that in the United States Zone MG Law No. 55 of Jan. 29, 1946, OG/MG, Issue A at 41 (June 1, 1946), and MGR 23.394, was necessary to prohibit transactions in stocks, bonds and other interests of the corporation.

85. Law No. 1 of Sept. 20, 1945 on "Repealing of Nazi Laws," OG/CC, No. 1 at 6 (Oct. 29, 1945), supplemented by Law No. 55 of June 20, 1947 on "Repeal of Certain Provisions of Criminal Legislation," OG/CC, No. 16 at 284 (July 31, 1947); Law No. 2 of Oct. 10, 1945 "Providing for the Termination and Liquidation of the Nazi Organizations," OG/CC, No. 1 at 19 (Oct. 29, 1945) ; Directive No. 50 of April 29, 1947 on "Disposition of Property Having Belonged to Organizations Listed in CC Proclamation No. 2 and CC Law No. 2" makes elaborate arrangements for the disposal of such property. The decision was delayed for a long time because it is closely connected with the extremely complex issue of the return of property of Nazi victims to their legitimate owners; for the United States Zone see MG Law No. 59 (effective Nov. 10, 1947) $O G / M G$, Issue $G$ at 1 . The Directive establishes the principle that property formerly belonging to trade unions, cooperatives, political parties, charitable, religious, humanitarian or other democratic organizations must be returned to them if they are still in existence (Art. II and III). Property which cannot be retransferred falls to the government of the Land or province where located (Art. V). Exempted are securities, cash accounts and monetary claims, the property of the Reich and of Reich organizations, and of the insurance companies connected with the German Labor Front (Art. IV); on the latter see CC Law No. 57 of Aug. 30, 1947 on "Dissolution and Liquidation of Insurance Companies Connected with the German Labor Front," OG/CC, No. 17 at 289 (Oct. 31, 1947).

Uniformity of denazification standards throughout the four zones is prescribed by 
(c) Administration of Justice and Law. While practically all enactments of the Council regardless of substance are rules of law in the wider connotation that they regulate human conduct, matters of law in the technical sense, that is, referring to the administration of justice and actions of private individuals, are dealt with by relatively few though substantially important legislative measures. ${ }^{\varepsilon 5}$ Topically they refer to the restoration of a democratic system of justice in general and the reorganization of the courts, ${ }^{87}$ including the re-establishment of labor ${ }^{88}$ and administrative courts; ${ }^{89}$ and to prisons, ${ }^{53}$ where the reforms substitute attempts at rehabilitation and reformation of the prisoner for the inhuman treatment he received from a regime boasting of its "virility."

the important Directive No. 24 of Jan. 12, 1946 on "Removal from .Office and from Positions of Responsibility of Nazis and of Persons Hostile to Allied Purposes," OG/CC, No. 5 at 98 (March 31, 1946), with amendment of Nov. 16, 1946, OG/CC, No. 12 at 228 (Nov. 30, 1946) ; in practice, however, wide differences exist among the four zones. Law No. 10 of Dec. 20, 1945 on "Punishment of Persons Guilty of War Crimes, Crimes against Peace and against Humanity," OG/CC, No. 3 at 50 (Jan. 31, 1946); Law No. 18 of March 8, 1946 on "Housing," OG/CC, No. 5 at 117 (Mfarch 31, 1946), Art. VIII, Ila; Directive No. 32 of June 26, 1946 on "Disciplinary dfeasures against Managing and Administrative Staffs of Educational Institutions, Teaching Staff, and Students Guilty of Militaristic, Nazi, or Anti-Democratic Propaganda," OG/CC, No. 8 at 162 (July 1, 1946) ; Law No. 31 of July 1, 1946 on "Police Bureaus and Agencies of a Political Nature," id. at 163. Of particular importance is Directive No. 38 of Oct. 13, 1946 on "The Arrest and Punishment of War Criminals, Nazis and Mfilitarists and the Internment, Control and Surveillance of Potentially Dangerous Persons," OG/CC, No. 11 at 184 (Oct. 31, 1946) implemented, with regard to economic matters, by Directive No. 57 of Jan. 15, 1948 on "Disposition of Property Confiscated under Control Council Law No. 10 or Legislation Issued Pursuant to Control Council Direetive No. 38," OG/CC, No. 18 at 302 (Jan. 31, 1948).

Law No. 48 of Miarch 10, 1947 on "Pre-Occupation Postage Stamps," OG/CC, No. 15 at 271 (May 31, 1947), orders the destruction of all such stamps found in postoffices and of their plates, molds and negatives; stamps issued under Weimar are not included. Directive No. 40 of Oct. 12, 1946 on "Policy to be Followed by German Politicians and the German Press," OG/CC, No. 11 at 212 (Oct. 31, 1946), issued at a time when everywhere in Germany elections for representative bodies were under way and a considerable degree of freedom of public opinion was restored to the Germans, prohibits expressions, statements or publications "which contribute to the spreading of nationalistic, pan-Germanic, militarist, fascist or anti-democratic ideas"; it may seem an interesting reflection of quadripartite semantics that the word "Nazi" is not used therein, evidently" being included in the term "fascist" according to Soviet usage.

86. Loewenstein, supra note 1.

87. Proclamation No. 3 of Oct. 20, 1945 on "Fundamental Principles of Judicial Reform," OG/CC, No. 1 at 22 (Oct. 29, 1945); Law No. 4 of Oct. 30, 1945 on "Rcorganization of the German Judicial System,",OG/CC, No. 2 at 26 (Nov. 30, 1945).

88. Law No. 21 of March 30, 1946 on "German Labor Courts," OG/CC, No. 5 at 124 (March 31, 1946).

89. Law No. 36 of Oct. 10, 1946 on "Administrative Courts," OG/CC, No. 11 at 183 (Oct. 31, 1946).

90. Directive No. 19 of Nov. 12, 1945 on "Principles for Administration of German Prisons," OG/CC, No. 3 at 46 (Jan. 31, 1946). 
Dealing with denazification of German law proper, the Council devoted its particular attention, after repeal of the most obnoxious Nazi statutes of a political nature, ${ }^{91}$ to criminal law. At the beginning of 1946 a major purge abrogated the most flagrant Nazi innovations in the criminal code, and also repealed seventeen auxiliary enactments of substantive and procedural content. ${ }^{22}$ This was supplemented in 1947 by a measure deleting sixteen additional criminal enactments, or parts thereof..$^{93}$

While in both of these instances the Council strictly confined itself to denazification by outright repeal, substantive reform of the criminal code, doubtless the most significant project of legal reform undertaken to date, has been in progress for more than two years. That the antiquated code, conceived in the spirit of the 1870's, requires modernization in line with democratic penology, ${ }^{94}$ has long been realized. An entirely new version was completed by a working party ${ }^{95}$ of the Legal Directorate in the fall of 1946. Its passage as a quadripartite measure was deferred for various reasons. It was found advisable to allow the German experts to advance their views on penal reform and to draft their own version if they so wished. Moreover, so long as there was a chance for the establishment of an indigenous German government, a reform of such magnitude, it was felt, should be left to the proper German parliamentary bodies. Yet in the light of experience-at the beginning of the century the Imperial Reichstag labored over a new criminal code for many years without result-and considering the continued absence of a central legislative agency, it seems unlikely that, within the foreseeable future, the Germans will attend to the task themselves. According to latest reports the quadripartite Committee on the

91. Law No. 1, of Sept. 20, 1945 on "Repealing of Nazi Laws," OG/CC, No، 1 at 6 (Oct. 29, 1945).

92. Law No. 11 of Jan. 30, 1946 on "Repealing of Certain Provisions of the Criminal Law," OG/CC, No. 3 at 55 (Jan. 31, 1946).

93. Law No. 55 of June 20, 1947 on "Repeal of Certain Provisions of Criminal Legislation," OG/CC, No. 16 at 284 (July 31, 1947).

94. Gruenhut, Development of the German Penal System 1920-1932, 22 CAN. B. REv. 196 (1944).

95. Each power delegated its best legal brains to the working party which later became the Committee on the Reform of the Criminal Code. Two members had had long experience in German law, the American as an attorney under the Republic, the Frenchman as a judge in a German court in Alsace before 1918. The committee carefully analyzed each provision of the code and redrafted many of those not even tainted by Nazi concepts. The completed draft was submitted to a conference of the chiefs of the administration of justice of the four zones, the first meeting of this kind, held in December, 1946. The Germans disagreed with the draft on various counts and drew up counter-proposals. See [1947] SJZ 119 and W. Römer, [1947] SJZ 97. The Committce on the Revision of the Criminal Code received also in the summer of 1947 the Americansponsored draft of the first part (covering \$\$1-239) of a new Code of Criminal Procedure. 
Revision of the Criminal Code has submitted its completed draft to the Legal Directorate for eventual adoption.

Less impressive are the accomplishments of the Council in the field of law and procedure. Of major importance is the new Marriage Law, ${ }^{\text {fi }}$ urgently called for by the flood of divorce petitions inundating the barely reopened courts. Substantially it is a compromise between the second and the third approaches to denazification of legislation; the Nazi-inspired parts of the statute of 1938 are eliminated and most of the technical improvements retained. The other-and, considering the increasing political paralysis affecting the Council, probably last-substantial measure for the denazification of German law was the repeal of the Nazi hereditary farm legislation..$^{97}$ Disagreement existed on all levels as to whether the Nazi farm legislation-which assigned farms of certain size permanently to the families owning them and forbade selling or mortgaging them except with official authorization-deserved retention in view of the strained food situation, even if stripped of its Nazi content. The Solomonic solution does away with the hereditary farms together with all other existing forms of special tenure and entails; but it substitutes for controls over certain lands wider controls over all agricultural and forest lands, subjecting all conveyance inter viros and the grant of interest in such lands entitling to the usufruct thereof to the approval of the German authorities.

Otherwise no major project in the field of legal reform was completed. Some minor measures affecting the codes were passed, one cutting out some Nazi provisions from the law of succession, ${ }^{93}$ the others of a merely technical nature conditioned by the emergency.5 In the field of legal reform proper the record of the Council is far from spectacular.

96. Law No. 16 of Feb. 20, 1946, OG/CC, No. 4 at 77 (Feb. 28, 1946), as amended by Law No. 52 of April 21, 1947, OG/CC, No. 15 at 273 (1Lay 31, 1947).

97. Law No. 45 of Feb. 20, 1947 on "Repeal of Iegislation on Hereditary Farms and Enactment of Other Provisions Regulating Agricultural Forest Lands," OG/CC, No. 14 at 256 (May 31, 1947); on the situation under the Nazi regime see Kaden, Pcasans Inheritance Law in Germany, 20 Iows L. REv. 350 (1935). For a discussion of the situation under the new CC law see Schetter, Dic Netordinung des Boderzerlechrsrechts, [1947] S]Z 370.

98. Law No. 37 of Oct. 30, 1946 on "Repeal of Certain Statutory Provisions Relating to Successions," OG/CC, No. 11 at 220 (Oct. 31, 1946); it abrogated $\S 48$, 12 of the law on testaments of July 31, 1938, [1938] RGB1. I, 973 (permitting modification of otherwise valid last wills by the courts in the public interest-which in practice had amounted to crude discriminations against disfavored persons and classes). The issue of the continued validity of the provision was controversial among the German legal profession; see Meiss, [1946] SJZ 65.

99. Law No. 24 of April 29, 1946 on "Repeal of the Law of September 30, 1936," OG/CC, No. 6 at 137 (April 30, 1946), concerning the inspection of certain judicial books and registers; Law No. 38 of Oct. 30, 1946 on "Amendment of Section 204 of the Code of Civil Procedure," OG/CC, No. 11 at 220 (Oct. 31, 1946). providing for appropri- 
(d) War Crimes. As a separate group, though cutting across the fields of denazification, demilitarization and administration of justice, may be considered the measures dealing with the trial of war criminals. ${ }^{100}$

(e) Taxation and Finance. It is noteworthy that the Control Council undertook a complete reconstruction of the German tax system, affecting direct and indirect taxation alike. ${ }^{101}$ Whether the very considerable increases in tax rates were conducive to the recovery of business in a broken-down economy may be open to discussion. But they helped to decrease the inflationary gap inherited from the high profits and the contracted supply of consumer goods of the Nazi period. Reforms of the collecting machinery, inspired by the home experiences

ate methods of service by publication necessitated by the breakdown of normal communications. The gap created by the discontinuation of the Reichsanzeiger, the official medium for the publication of official notices, was filled by Land legislation; for WürttembergBaden see Law No. 26 of April 11, 1946, [1946] REG. BL. 152.

100. Law No. 10 of Dec. 20, 1945 on "Punishment of Persons Guilty of War Crimes, Crimes against Peace and against Humanity," OG/CC, No. 3 at 50 (Jan. 31, 1946), and the additional Directive No. 38 of Oct. 12, 1946 on "Arrest and Punishment of War Criminals, Nazis and Militarists and the Internment, Control and Surveillance of Potentially Dangerous Persons," OG/CC, No. 11 at 184 (Oct. 31, 1946); see also Directive No. 57 of Jan. 15, 1948 on "Disposition of Property Confiscated Under Control Council Law No. 10 or Legislation Issued Pursuant to Control Council Directive No. 38," Art. VIII, OG/CC, No. 18 at 302 (Jan. 31, 1948).

101. Legislation on the following individual taxes was revised:

Income, corporation and excess profit taxes: Law No. 12 of Feb. 11, 1946, OG/CC, No. 4 at 606 (Feb. 28, 1946), amended by Law No. 42 of Nov, 30, 1946, OG/CC, No. 12 at 231 (Nov. 30, 1946) and Law No. 61 of Dec. 19, 1947, OG/CC, No. 18 at 297 (Jan. 31, 1948).

Property (Vermögenssteuer): Law No. 13 of Feb. 11, 1946, OG/CC, No. 4 at 71 (Feb. 28, 1946), amended by Law No. 59 of Oct. 20, 1947, OG/CC, No. 17 at 294 (Oct. 31, 1947).

Motor vehicles: Law No. 14 of Feb. 11, 1946, OG/CC, No. 4 at 73 (Feb. 28, 1946), amended by Law No. 51 of March 31, 1947, OG/CC, No. 14 at 267 (March 31, 1947).

Turnover tax (Umsatzstetser): Law No. 15 of Feb. 11, 1946, OG/CC, No. 4 at 75 (Feb. 28, 1946).

Inheritance: Law No. 17 of Feb. 28, 1946, id. at 94.

Tobacco: Law No. 26 of May 10, 1946, OG/CC, No. 7 at 146 (May 31, 1946). The inordinately high rates placed on those commodities as essential to the morale of the population as food were slightly reduced by Law No. 41 of Nov. 30, 1946, OG/CC, No. 12 at 229 (Nov. 30, 1946).

Alcohol: Law No. 27 of May 10, 1946, OG/CC, No. 7 at 149 (May 31, 1946); amended by Law No. 54 of June 10, 1947, OG/CC, No. 16 at 284 (July 31, 1947). 1946).

Beer and matches: Law No. 28 of May 10, 1946, OG/CC, No. 7 at 150 (May 31,

Sugar: Law No. 30 of June 20, 1946, OG/CC, No. 8 at 161 (July 1, 1946).

Taxes on insurance: Law No. 53 of May 31, 1947 on "Amendment to the Insurance Tax Law of July 9, 1937," OG/CC, No. 15 at 282 (May 31, 1947); telephone and telegraph rates likewise were steeply raised by Law No. 20 of March 20, 1946, OG/CC, No. 5 at 123 (March 31, 1946). 
of the Anglo-American powers-the "pay-as-you-go" system had existed under the Republic-did not result in simplification. ${ }^{202}$ To obtain reparations and to forestall an eventual Nazi revival originating abroad, the Council seized German external assets by vesting in a quadripartite German External Assets Commission all rights, titles and interests in respect of any property outside Germany owned or controlled by any person of German nationality. ${ }^{103}$

(f) Economic Life, next to demilitarization and denazification, was the subject to which the Council devoted most of its legislative efforts.

With respect to labor the occupying powers, despite their divergent social and political ideals, were able to reach agreement on many basic issues, although repeal of the Nazi "Labor Charter" of 1934, on which Nazi control over labor was founded, was delayed until the end of 1946. ${ }^{104}$ In general, quadripartite regulations confined themselves to setting forth uniform principles or standards for Germany as a whole and charged the Land labor authorities with implementation and execution, under general supervision by the Zone Commanders. At an early date common wage policies were agreed upon and the right of the resurrected trade unions recognized to negotiate with employers and employers' associations concerning wage adjustments; but changes in the rate structure of wages were made dependent on authorization by the Land labor agencies. ${ }^{105}$ Other measures dealt with working hoursfixing the normal work week at forty-eight hours ${ }^{100}$-labor supply and the labor market. The rigid control of labor that had existed under the

102. See Die Steuergesetze des Kontrollrats, [1945-46] DrE Waxplusa 1003.

103. Law No. 5 of Oct. 30, 1945 on "Vesting and Mrarshalling of German Extermal Assets," OG/CC, No. 2 at 27 (Nov. 30, 1945), with Regulation No. 1 of 11ay 10, 1946, OG/CC, No. 8 at 160 (July 1, 1946). See also Directive No. 21 of Nov. 20, 1946 on "The Activation of the German External Property Commission," MIGR 23.161.21. The law affects persons who since September 1, 1939 enjoyed full German citizenship rights, thus exempting Jews and other persons who were exiled before or after, and it does not pertain to countries which Germany had annexed since December 31, 1937. It created many legal and political difficulties because neutral countries do not recognize the $C C$ as the German central government under international law. (On this aspect see Kelsen, Legal Status of Germany According to the Declaration of Berlin, 39 A2r. J. Init'L L. 518 (1945)). Negotiations with Switzerland, Sweden, and presumably other neutral states were required to obtain some of the results desired.

104. Law No. 40 of Nov. 30, 1946 on "Repeal of the Law of January 20, 1934 on The Organization of National Labor," OG/CC, No. 12 at 229 (Nov. 30, 1946). Sce also Law No. 56 of June 30, 1947 on "Repeal of the Law of March 23, 1934, on the Regulntion of Labor in Public Administrations and Enterprises," OG/CC, No. 16 at 287 (July 31, 1947).

105. Directive No. 14 of Oct. 12, 1945 on "Wage Policy," OG/CC, No. 3 at 40 (Jan. 31, 1946). Wage increases in the mining industry, key to German economic rehabilitation, were authorized by Directive No. 41 of Oct. 17, 1946, OG/CC, No. 11 at 213 (Oct. 31, 1946).

106. Directive No. 26 of Jan. 26, 1946 on "Regulation of Working Hours," OG/CC, No. 5 at 115 (March 31, 1946). 
Nazi regime was continued by placing labor supply, regardless of the lind of work, under the exclusive jurisdiction of the German labor authorities, assigning to them also the right "in case of necessity to place persons in work by compulsory direction"; even the employment of unemployed persons or the transfer of employees from one place of work to another was forbidden unless by permission of the labor offices. ${ }^{107}$ Democratization of, and self-government within, the labor movement were strengthened by the creation of federations of trade unions ${ }^{108}$ - a measure loaded with political dynamite in view of the competition of the political parties for their control-by the development of advisory councils attached to the Labor Offices; ${ }^{100}$ by the revival of works councils (Betriebsräte) ${ }^{110}$ that had existed, without signal success, under Weimar; and, last but not least, by an elaborate system of labor courts and arbitration agencies for settlement of labor disputes. ${ }^{111}$

In contrast to labor, divergence of zonal policies in agriculture could not be reconciled by quadripartite regulations. It will be remembered that the inability of the Council to agree on common food policies was among the reasons that induced the Anglo-American powers to embark on the bizonal experiment. The only major reform was the elimination of the hereditary farms and the substitution of comprehensive new controls ${ }^{112}$ to which may be added the repeal of extraordinary measures on leases, agricultural management and debtor relief enacted by the Nazis in 1944. ${ }^{113}$

Among other enactments of the Council in the field of economics was one concerning housing ${ }^{114}$ which regulated one of the most vexing problems of a devastated and overpopulated country by strictly rationing housing space and assigning, through certain priorities, available space to those needing it most. No less essential for the daily life of the

107. Order No. 3 of Jan. 17, 1946 on "Registration of the Population of Employable Age, Registration of Unemployed and their Placement at Work," OG/CC, No. 6, at 131 (April 30, 1946); see especially Nos. 18 and 16 of the Order; Law No. 32 of July 10, 1946 on "Employment of Women on Building and Reconstruction Work," OG/CC, No. 9 at 166 (July 31, 1946).

108. Directive No. 31 of June 3, 1946 on "Principles Concerning the Establishment of Federations of Trade Unions," OG/CC, No. 8 at 160 (July 1, 1946).

109. Directive No. 29 of May 17, 1946, OG/CC, No. 7 at 153 (May 31, 1946).

110. Law No. 22 of April 10, 1946, OG/CC, No. 6 at 133 (April 30, 1946).

111. Law No. 21 of March 30, 1946 on "German Labor Courts," OG/CC, No. 5 at 124 (March 31, 1946) ; Law No. 35 of Aug. 20, 1946 on "Conciliation and Arbitration Machinery in Labor Conflicts," OG/CC, No. 10 at 174 (Aug. 31, 1946).

112. Law No. 45 of Feb. 20, 1947 on "Repeal of Legislation on Hereditary Farms and Enactment of other Provisions Regulating Agricultural Forest Lands," OG/CC, No. 14 at 256 (March 31, 1947).

113. Law No. 44 of Jan. 10, 1947, id. at 256.

114. Law No. 18 of March 8, 1946, OG/CC, No. 5 at 117 (March 31, 1946). 
people was the rationing of gas and electricity. ${ }^{115}$ The desperate food situation compelled the Control Council to threaten severe penalties (including hard labor for life) for black market activities and the theft and unlawful use of rationed foodstuffs. ${ }^{110}$ In line with the policy of economic deconcentration, German insurance companies were forbidden to accept insurance or re-insurance of risks located outside Germany, thus confining their activities exclusively to the internal market. ${ }^{117}$

(g) Administrative Affairs. Other measures refer to administrative matters requiring uniform regulation by a central agency, such as adopting standard time throughout Germany; ${ }^{118}$ arranging for a population census; ${ }^{119}$ and certain arrangements incidental on the occupation and its technical requirements. ${ }^{120}$

(h) Civil Liberties and Cultural Affairs. Disappointingly meagerreflecting the conflicting political ideologies of the occupation powers and the isolation of each zone from the others-are the accomplishments of the Council in the political and cultural field. The record shows four measures only: one rescinding the Nazi effort to control, by unification, the Evangelical Church; ${ }^{121}$ another repealing the Nazi leg-

115. Law No. 7 of Nov. 30, 1945, OG/CC, No. 2 at 32 (Nor. 30, 1945); to cut down the excessive use of these commodities, rates and penalties were considerably stiffened by Law No. 19 of Mrarch 20,1946, OG/CC, No. 5 at 122 (Mfarch 31, 1946).

116. Law No. 50 of MFarch 20, 1947 on "Punishment for the Theft and Unlswiul Use of Rationed Foodstuffs, Goods and Rationing Documents," OG/CC, No. 14 at 260 (Mfarch $31,1947)$.

117. Law No. 47 of March 10, 1947 on "Termination of German Insurance Operations Abroad," $i d$. at 263. In July, 1946 the managers of the Btinschener Rivelacrsicherssggsgesellschaft, formeriy the most powerful insurance concern on the continent and a prominent tool of Nazi economic penetration, were tried and convicted for concealing forcign assets.

118. Directive No. 15 of Oct. 26, 1945, OG/CC, No. 3 at 41 (Jan. 31, 1946).

119. Law No. 33 of July 20, 1946, OG/CC, No. 9 at 166 (July 31, 1946).

120. Law No. 39 of Nov. 12, 1946 on "Distinguishing Flag to be Worn by" German and Ex-German Ships Operating Under Allied Control Authority," OG/CC, No. 12 at 226 (Nov. 30, 1946) ; Directive No. 36 of Sept. 13, 1946 on "Establishment of an Allied Control Authority Interzonal Facilities Bureau," MIGR 23.161.36; Directive No. 42 of Oct. 24, 1946 on "Movement Across Demarcation Lines of German Workers and Employees Residing in One Zone and Working in Another," OG/CC, No. 11 at 213 (Oct. 31, 1946) ; Directive No. 43 of Oct. 29, 1946 on "Procedure for the Issue to German Civilians of Single Roundtrip Inter-zonal Passes for a Journey Outside the Zone for Purposes of Interzonal Trade," id. at 215, amended by Directive No. 49 of April 23, 1947, OG/CC, No. 15 at 274 (Mray 31, 1947); Directive No. 27 of March 18, 1946 on "Administration of Social Insurance Applicable to German Civilian Workers Employed by the Allied Occupational Authorities," OG/CC, No. 7 at 146 (Mfay 31, 1946) ; Law No. 6 of Nov. 10, 1945 on "Safeguarding of Documents and Delivery of Conforming Copies," OG/CC, No. 2 at 31 (Nov. 30, 1945), amended by Law No. 29 of $\mathrm{M} 33 y$ 31, 1946, OG/CC, No. 7 at 156 (11ay 31, 1946), whereby each occupying power is entitled to receive certified copies of any document pertaining to any business or governmental agency.

121. Law No. 49 of March 20, 1947 on "Repeal of Reich Law of July 14, 1933 Concern- 
islation which brought the film industry and the motion picture business under state control; ${ }^{122}$ the third granting German democratic parties and the press the right of free discussion of German political problems, within the limits of military security; ${ }^{123}$ and the last, in accordance with the decision of the Moscow Conference of the Foreign Ministers, authorizing the free flow throughout Germany of newspapers, magazines, periodicals, films and books. ${ }^{124}$

(i) Health. Finally, a rather unique measure presents the Council as the guardian looking after the well-being of its ward in an effort to combat venereal diseases. ${ }^{125}$ "Disturbed by the increased incidence of venereal disease," the Council severely censured the German authorities, stating that it was "convinced that one of the causes of this increase lies in the ineffectiveness of the German law at present in force." The Zone Commanders were instructed to examine the existing German legislation. A draft law on the control of venereal diseases was attached to serve for their guidance in the establishment of uniform control measures throughout their zones. The case illustrates sharply the necessity of a central agency for Germany as a whole since in many fields measures will remain ineffective unless uniformly applied.

\section{(4) General Evaluation of Control Council Legislation}

Considered as a whole the legislative activity of the Council is impressive. Up to January 31, 1948 three proclamations, four orders, sixty-one laws, and fifty-seven directives were approved, many of them voluminous documents of technically intricate content. The total output cannot fail to command respect when allowance is made for the enormous operational difficulties. The legislative efforts of a quadripartite and tri-lingual body, with constantly shifting personnel, not only are applied to a national environment alien to the officials of all four powers but, in addition, require antecedent harmonization of

ing the Constitution of the German Evangelical Church," OG/CC, No. 14 at 265 (March $31,1947)$. On the activities of AMG to encourage and guide a religious revival in the United States Zone, see KNAppen, ANd Call it PeAce 48, 94, 110 (1947) ; for quadripartite efforts in the religious field, see $i d$. at 145 et seq.

122. Law No. 60 of Dec. 19, 1947, "Repealing Nazi Legislation on Motion Pictures," OG/CC, No. 18 at 296 (Jan. 31, 1948).

123. Directive No. 40 of Oct. 12, 1946 on "Policy to be Followed by German Politicians and the German Press," OG/CC, No. 11 at 212 (Oct. 31, 1946).

124. Directive No. 55 of June 25, 1947 on "Interzonal Exchange of Printed Matter and Films," OG/CC, No. 16 at 286 (July 31, 1947). The measure, intended "to facilitate a further development of the democratic German press," has not lived up to the expectations of the Western powers because the better newsprint supply in Eastern Germany permits the Soviet-licensed press to flood the other zones. The Directive grants the respective Zone Commanders the right to submit desired restrictive measures to the quadripartite Information Committee of the Political Directorate of the CC.

125. Directive No. 52 of May 7, 1947, OG/CC, No. 15 at 281 (May 31, 1947). 
four divergent political and socio-economic approaches. This explains why in many instances legislation must confine itself to the statement of general principles and leave their actualization to the Zone Commanders and the German authorities subordinate to them. This situation is also responsible for the drafting methods which, as a compromise between four different techniques, cannot fail to be frequently at variance with German habits. More recent legislation overcame this incongruity with more success, and German authorities and courts, at first respectfully bewildered, have begun to apply and interpret Control Council acts with greater facility.

Although the task of legislating the Potsdam program into practice was undertaken wholly pragmatically and without any advance planning, in due course its major contours became clearly recognizable. Legislation to eliminate Nazism and militarism is sufficiently progressed, if not yet complete, to prevent as effectively as is possible on paper the revival of the institutions on which they were based and the mechanics by which they were operated. The spirit, of course, cannot be commanded, and there is as yet no such thing in international affairs as eternal vigilance.

In other fields, likewise, the implementation of Potsdam is less skeletal than is assumed generally. In the field of legal reform uniform principles exist for the administration of justice and are being applied throughout Germany. Otherwise the accomplishments in this field are modest; to expect that foreign lawyers would be able to reform the substance of indigenous German law was perhaps unreasonable to begin with. In the economic field quadripartite achievements aimed at uniform rules for labor and manpower are satisfactory, and those intended to reduce the economic potential of an aggressor nation are not altogether lacking. On the negative side, however, it is the almost complete absence of agreement among the four powers on political structure, reflected by the paucity of pertinent quadripartite legislation, which appears as the outstanding failure of Council activity.

There can be no doubt that the Control Council has reached and passed the zenith of its legislative energy, as outwardly evidenced by the thinness and sterility of the later issues of the Official Gazette when compared with the previous ones. The recession may be ascribed to two different causes. Although the Council and its component parts remain the businesslike and hardworking organization they were from the beginning, basic disagreements among the four governments result in more and more projects being deferred, shelved and pigeon-holed. Legislative stagnation reflects the general political situation of the progressive alienation of the Anglo-American Powers from the other two, although the reasons differ in the cases of the French and the Soviets. Vanishing political concordance on the highest level could not fail to impair the effectiveness of the Council and to infuse a sense 
of unreality and frustration into work, which, at least prior to the failure of the conference of foreign ministers in London in December: 1947 , had been conducted under the assumption of jointly implementing the Potsdam objectives. But the contraction of Control Council legislation must also be traced to the revival of German political life resulting, by the end of 1947, in the establishment everywhere of parliamentary bodies in working condition. Here the paradox exists that the more the legislative apparatus of five, or, rather, seventeen segments into which Germany is split today, succeeds into and supersedes the legislative authority of the Council, the more imperative becomes their coordination. But any revitalization of the Allied Control Authority will come-assuming that quadripartite tutelage over the confiscated sovereignty of Germany is maintained-only with the establishment of a central German government for it to guide and supervise. For this latter development, the prospects seem dimmer than at any time since Potsdam. It may well be that a new chapter of postwar German history is about to open.

This summary appraisal of the latest stages of quadripartite administration of Germany under the Potsdam Declaration may well have to serve as an obituary. The meeting of the Control Council of March 20 was broken off by the Soviet delegate on the ground that the AngloAmerican members had declined his request for information on the recent London conference of the Western Powers. This meeting, aimed at a closer economic integration of the three western zones, was felt by the Russians to be in conflict with Potsdam. Though available reports seem to indicate that the Soviets were willing to continue the quadripartite work of the directorates and other subcommittees as scheduled, General Clay's subsequent decision not to call the regular meeting of April 10 must be taken as evidence of the intention of the Anglo-American partners to terminate an institution considered useless under present circumstances. Thus, after thirty-two months of operation, joint four-power rule over Germany has come to its end. 